Article

\title{
China's economy growth prospects and its potential drivers of future
}

\author{
Jean-Noël BEKA BE NGUEMA \\ Central University of Finance and Economics, Beijing, China \\ Correspondence: jeannoel.beka@yahoo.fr \\ Academic Editor: Helmi Hamdi
}

Received: date; Accepted: date; Published: date

\begin{abstract}
The purpose of this paper is to apply China's economy growth prospects and its potential drivers of future. China's fast rise and its growth model have accelerated important existing structural trends in the global economy and made them decisive characteristics of the world economy. China's role in the world economy over the coming decades, an exercise which would not be possible without an investigation of the prospects for China's continued economic rise. On the one hand, China is a large export market for the United States. A lot of U.S. firms use China as the final destination of assembly in their global supply chain networks. China's huge holdings of U.S. Treasury securities support the federal government finance its budget failures. However, some analysts contend that China consolidates a number of distortive economic policies such as protectionist industrial policies and an undervalued currency that undermine U.S. economic interests. They warn that efforts by the Chinese government to promote indigenous innovation, often through the use of subsidies and other distortive measures, could negatively affect many leading U.S. industries.
\end{abstract}

Keywords: China, economic growth, export market, economic policy, potential drivers JEL Classification:

\section{Introduction}

China's rapid economic growth has led to a substantial rise in bilateral commercial ties among many countries such as the United States. According to U.S. trade report, total trade between the two countries increased from $\$ 5$ billion in 1980 to almost $\$ 562$ billion in 2013. China is currently the United States' second-largest trading partner, its third-largest export retail, and its largest source of imports. A lot of U.S. firms have a large operations in China in order to sell their goods in the booming Chinese market and to take profit of lower-cost labor for export-oriented manufacturing. These operations have supported some U.S. Companies to consolidated internationally competitive and have supplied U.S. consumers with a variety of low-cost goods. China's huge-scale 
purchases of U.S. Treasury securities have enabled the federal government to fund its budget failures, which help keep U.S. interest rates relatively low.

On the other hand, the emergence of China as a large economic power has increased concern between various U.S. policy makers. Some request that China applies unfair trade process to flood U.S. retails with low-cost goods, and that such approaches threaten American activities, wages, and living standards. Others contend that China's rising apply of industrial policies to boost and secure certain domestic Chinese industries or firms favored by the government, and its failure to take efficient action against widespread infringement of U.S. intellectual property rights in China, threaten to undermine the competitiveness of U.S. IP-intensive industries.

Further, while China has become a large and growing retail for U.S. exports, critics contend that various trade and investment barriers border opportunities for U.S. companies to sell in China, or force them to set up production facilities in China as the price of doing business there. Other points relating to China's economic growth include its increasing demand for energy and raw materials and its emergence as the world's largest emitter of greenhouse gasses. The purpose of this paper is to apply China's economy growth prospects and its potential drivers of future.

According to Tong, J. T et al.(2017) China has a population three times more than all other transition economies combined, and China's economic development in the last two decades has been nothing short of phenomenal, having overtaken Japan as the world's second-largest economy. China's future economic growth, social and political stability will undoubtedly have an unprecedented influence on the order and fiscal stability of the Chinese people.

Overholt, W. H. (2016) also found that China's rapid growth and its growth model have accelerated important existing structural trends in the world economy and made them decisive characteristics of the global economy. In particular, China has ensured that this will be the era of the global market economy; the super-industrial economy; the post-

industrial economy; the ecologically constrained economy; the complex economy; the highly globalized economy; the innovation economy; an economy with a new moral consciousness about the global supply chain; and an economy with an emerging new monetary system. Lin, J et al.(2016) argued that after more than three decades of unprecedented high growth at an average rate of nearly $10 \%$ per annum, China's economy has been slowing down since 2010, dropping to $6.9 \%$ in 2015, the lowest annual growth rate since 1990. As the world's largest economy in PPP terms and the second largest in terms of nominal exchange rates, such a slowdown has profound implications. 
Glawe, L et al. (2017)developed a stylized multi-sector growth model of China's economy. Authors applied a neoclassical modeling approach and focus on the reform process under Deng Xiaoping as China’s main growth driver since 1978.

A study by Ma, G et al.(2017) considers interactions between China's domestic and external imbalances and their global implications. Authors presented scenarios detailing how a rebalancing of China's growth pattern from investment-driven growth towards more consumption-driven growth may occur in practice. Using input-output tables for 2012, scholars illustrated the knife-edged nature of Chinese rebalancing, the linkages between expenditure-side and production-side rebalancing, and how an internal rebalancing could exacerbate external imbalances.

More scholars for instance, Tong, J. T et al.(2017) also argued that China has a population three times more than all other transition economies combined, and China's economic development in the last two decades has been nothing short of phenomenal, having overtaken Japan as the world's second-largest economy. China's future economic growth, social and political stability will undoubtedly have an unprecedented influence on the order and fiscal stability of the Chinese people.

Accoding to Liu, W. H et al. (2016) against the background of the continuously weaker economic growth in China in the past few years, the Chinese government is convinced that the Chinese economy needs to adapt itself to getting used to "the New Normal". Under "the New Normal" the Chinese economy will grow at lower rates of about 6-7\% annually, whereas China would strive for substantial quality advancement that should become a core element in its future growth model in the long run.

Gao, Z. (2017) points out that it has been nearly four decades since China initiated its economic reform in 1978. In spite of the fact that it brought the unprecedented economic growth to China, the reform is viewed by many as problematic, and has recently seemed to be caught in the dilemma between recession and inequity.

The author intends to explore the structural flaws of China's economic reforms in the light of modern Catholicsocial teaching, especially the basic theological principles it builds in 
explicating activities in political-economic spheres. On the basis of the Catholic understanding of economic liberty, market, government, and equity, the scholar also tries to provide a public theological agenda for China's economic reforms, in order to help solve the problems they are facing.

Further authors for example, Alder, S et al.(2016) have applied the effect of place-based industrial policy on economic development, focusing on the establishment of Special Economic Zones (SEZ) in China. Authors used data from a panel of Chinese (prefecture-level) cities from 1988 to 2010. Their difference-in-difference estimation exploited the variation in the establishment of SEZ across time and space.

Authors found that the establishment of a state-level SEZ is associated with an increase in the level of GDP of about $20 \%$.

\section{China's Economic Growth}

According to Tong, J. T et al.(2017) China has a population three times more than all other transition economies combined, and China's economic development in the last two decades has been nothing short of phenomenal, having overtaken Japan as the world's second-largest economy. China's future economic growth, social and political stability will undoubtedly have an unprecedented influence on the order and fiscal stability of the Chinese people.

Overholt, W. H. (2016) also found that China's rapid growth and its growth model have accelerated important existing structural trends in the world economy and made them decisive characteristics of the global economy. In particular, China has ensured that this will be the era of the global market economy; the super-industrial economy; the post-

industrial economy; the ecologically constrained economy; the complex economy; the highly globalized economy; the innovation economy; an economy with a new moral consciousness about the global supply chain; and an economy with an emerging new monetary system. Lin, J et al.(2016) argued that after more than three decades of unprecedented high growth at an average rate of nearly $10 \%$ per annum, China's economy has been slowing down since 2010 , dropping to $6.9 \%$ in 2015 , the lowest annual growth 
rate since 1990. As the world's largest economy in PPP terms and the second largest in terms of nominal exchange rates, such a slowdown has profound implications.

Glawe, L et al. (2017)developed a stylized multi-sector growth model of China's economy. Authors applied a neoclassical modeling approach and focus on the reform process under Deng Xiaoping as China’s main growth driver since 1978.

A study by Ma, G et al.(2017) considers interactions between China's domestic and external imbalances and their global implications. Authors presented scenarios detailing how a rebalancing of China's growth pattern from investment-driven growth towards more consumption-driven growth may occur in practice. Using input-output tables for 2012, scholars illustrated the knife-edged nature of Chinese rebalancing, the linkages between expenditure-side and production-side rebalancing, and how an internal rebalancing could exacerbate external imbalances.

More scholars for instance, Tong, J. T et al.(2017) also argued that China has a population three times more than all other transition economies combined, and China's economic development in the last two decades has been nothing short of phenomenal, having overtaken Japan as the world's second-largest economy. China's future economic growth, social and political stability will undoubtedly have an unprecedented influence on the order and fiscal stability of the Chinese people.

Accoding to Liu, W. H et al. (2016) against the background of the continuously weaker economic growth in China in the past few years, the Chinese government is convinced that the Chinese economy needs to adapt itself to getting used to "the New Normal". Under "the New Normal" the Chinese economy will grow at lower rates of about 6-7\% annually, whereas China would strive for substantial quality advancement that should become a core element in its future growth model in the long run.

\section{China's Economic Growth and Reforms: 1979-the Present}

Since the establishment of economic reforms, China's economy has increased substantially faster than during the pre-reform episode. The Chinese government argues 
that, from 1953 to 1978, real annual GDP growth was almost 6.7\%, although a lot of analysts point out that Chinese economic data during this time bring huge inquiries because Chinese government officials often exaggerated production levels for a variety of political causes.

China's economy endured economic declines during the leadership of Chairman Mao Zedong, including during the Great Leap Forward from 1958 to 1960 . Since 1979, China's average annual real GDP has increased by nearly 10\% (see Figure 1).

This has meant that, on average, China has been strong to double the capacity of its economy in real terms every eight years. The global economic crisis, which began in 2008, affected the Chinese economy. China's real GDP growth declined from $14.2 \%$ in 2007 to $9.6 \%$ in 2008 , and slowed to $9.2 \%$ in 2009. As return, the Chinese state brings a large economic stimulus action and a significant monetary policy. These measures significantly impacted domestic investment and consumption and supported prevent a sharp economic recession in China. From 2009 to 2011, China's real GDP increased averaged 9.6\%. China's economy has decreased in recent years-real GDP grew by 7.7 in 2012 and 2013. According to International Monetary Fund, China's real GDP will average $7.0 \%$ from 2014 to 2019 .

Figure 1. Chinese Real GDP Rise: 1979-2013 


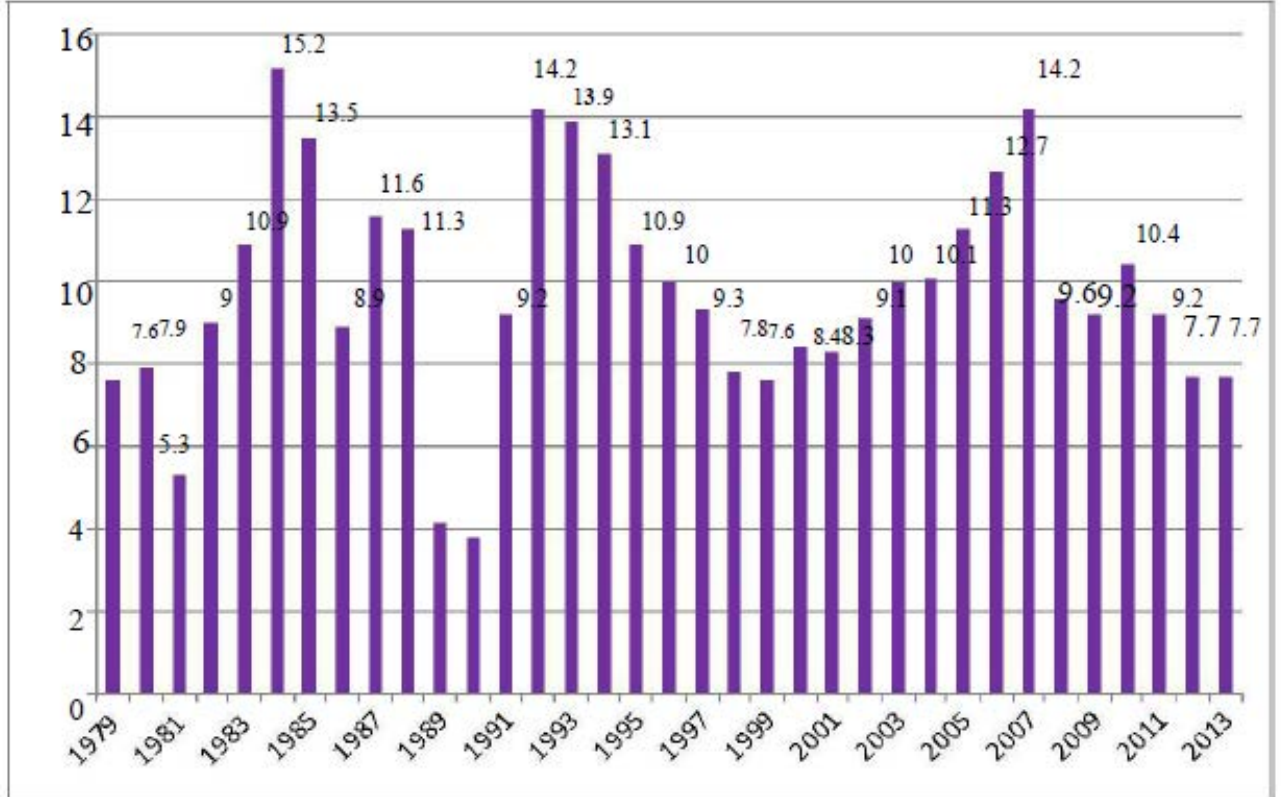

\subsection{Causes of China's Economic Growth}

Many scholars generally attribute much of China's fast economic rise to two significant factors such as large-scale capital investment and fast productivity growth. These two factors emerged to have gone together. Economic reforms force to higher efficiency in the economy, which impacted profits and increased resources for further investment in the economy.According to Zhengge, T. U et al.(2016) China's economy has experienced a high-rate growth since the reform and opening up in 1978. However, some macro-statistics indicated that China's economy grows with a low efficiency. In fact, these conclusions based on macro-statistics and the performance of the economy as a whole cannot reflect the multi-level, dynamic and, therefore, complicated situation of China.

A study by Wilson, R. (2016) brings the causal relationships between quality of governance and economic growth at the provincial level in China during the post-Mao reform era. Exploiting the wide cross-provincial variation and rapid change over time in governance institutions and economic performance in China during this period (covering 1985-2005), Author provides a new perspective on the relationship between governance and growth. Whereas a large body of prior literature has demonstrated a strong positive association between high-quality governance institutions and good economic performance at the cross-country level, few quantitative studies have explicitly tested the direction of causality between changes in governance quality and changes in economic outcomes. 
China's three-decade infrastructure investment boom shows few signs of abating. Is China's economic growth a consequence of its purposeful investment? Is China a prodigy in delivering infrastructure from which rich democracies could learn? The prevalent view in economics literature and policies derived from it is that a high level of infrastructure investment is a precursor to economic growth. China is especially held up as a model to emulate Ansar, A et al.(2016). Different scholar hold different views with the relationship of international capital flows and economic growth. By China international capital flows on economic growth influence the empirical analysis, this article believes that the international capital flows on economic growth exist both positive effect and negative effect Xianhong, X., Tian, C et al.(2016, December).Despite, as China's technological improvement onset to approach that of main developed countries, its level of productivity gains, and so, real GDP rise, could slow significantly from its historic levels except China becomes a main center for advance technology and innovation and/or implements recent comprehensive economic reforms. Many developing economies practiced fast economic development and increase during the 1960s and 1970s by implementing some of the same policies that China has applied to date to develop its economy, such as measures to improve exports and to boost and secure certain industries.

However, at some size in their development, some of these countries began to experience economic stagnation over a sustained episode of time, a phenomenon described by economists as the "middle-income trap. According to a prospective of The Economist Intelligence, China's real GDP growth will slow significantly in the years along, averaging 6.1\% from 2014 to 2020, and 2.3\% from 2021 to 2030 (Figure 2).

The Chinese government has points out its ambition to move away from its current economic approach of rapid growth at any cost to more " efficient" economic rise, which looks to cut down dependence on energy-intensive and high-polluting industries and rely more on high technology, green energy, and services. China also has figures out it wants to access further balanced economic growth. 
Figure 2. Projections of U.S. and Chinese Annual Real GDP Growth Rates: 2014-2030

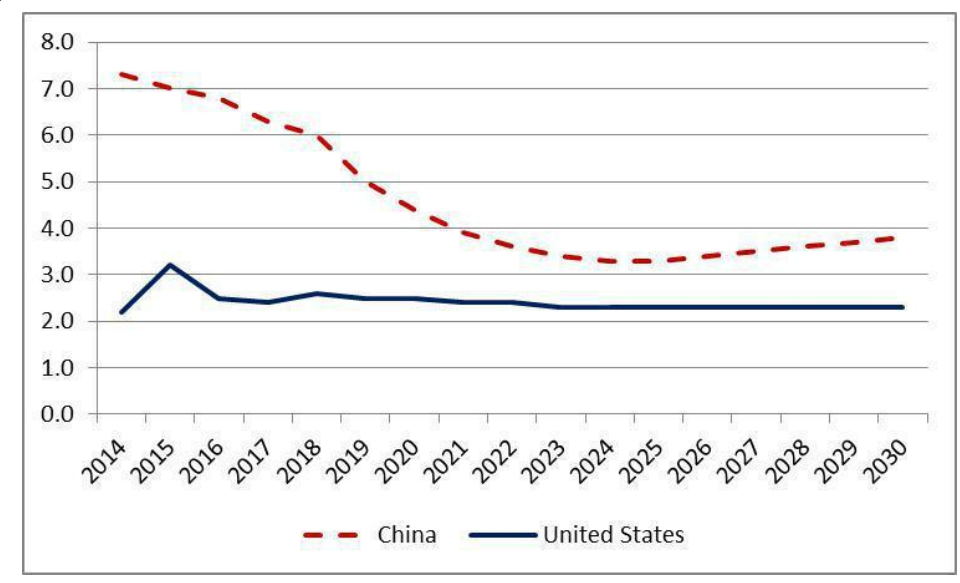

Source: Economist Intelligence Unit.

\subsubsection{Measuring the Size of China's Economy}

The fast growth of the Chinese economy has motivate a lot of scholars to figure out if and when China will overtake the United States as the "world's largest economic power." The "actual" size of China's economy has been a main subject of large-scale controversy between economists. Measured in U.S. dollars applying nominal exchange quotas, China's GDP in 2013 was $\$ 9.3$ trillion, about 55\% the volume of the U.S. Economy. The per capita GDP of China was $\$ 6,900$, which was $18 \%$ the capacity of Japan's level and $13 \%$ that of the United States (see Table 1).

Many scholars argued that applying nominal exchange rates to convert Chinese data into U.S. dollars break down to provide the real volume of China's economy and living standards relative to the United States. Nominal exchange rates simply show the prices of foreign currencies with the U.S. dollar and such measurements exclude differences in the prices for goods and services across countries. Hence, one dollar exchanged for local Japanese currency would buy fewer goods and services there than it would in the United States. 
The PPP exchange rate rises the measurement of China's economy and its per capita GDP. According to the EIU, which applies World Bank data, prices for goods and services in China are about $45 \%$ the level they are in the United States. Adjusting for this price differential increases the expense of China's 2013 GDP from $\$ 9.3$ trillion to $\$ 16.1$ trillion .This would show that China's economy is $95.9 \%$ the volume of the U.S. economy. China's share of global GDP on a PPP basis increased from 3.7\% in 1990 to $18.2 \%$ in 2013, while the U.S. share of global GDP increased at $24.3 \%$ in 1999 and decreased to $19.0 \%$ in 2013.

Further economic analysts project that on a PPP basis China will soon overtake the United States as the world's largest economy. Brooks, S. G et al.(2016) also argued that after two and a half decades, is the United States' run as the world's sole superpower coming to an end? Many say yes, seeing a rising China ready to catch up to or even surpass the United States in the near future.According to authors by many measures, after all, China's economy is on track to become the world's biggest, and even if its growth slows, it will still outpace that of the United States for many years. (see Figure 3), and that by 2030, China's economy could be $36.1 \%$ larger than that of the United States. This would not be the first time in history that China was the world's largest economy. The PPP measurement also raises China's 2013 nominal per capita GDP (from \$6,700) to $\$ 10,940$, which was $22.5 \%$ of the U.S. level. The EIU projects that, even by the year 2030, U.S. living averages will be close to three times greater than those in China.Hence, although China could become the world's largest economy in a few years on a PPP basis, it will likely take many years for its living standards to approach U.S. Levels.

Table 1. Comparisons of Chinese, Japanese, and U.S. GDP and Per Capita GDP in Nominal U.S. Dollars and a Purchasing Power Parity Basis: 2013

\begin{tabular}{lrrr} 
& \multicolumn{1}{l}{ China } & Japan & United States \\
& & & \\
\hline Nominal GDP (\$ billions) & 9,323 & 4,901 & 16,800 \\
GDP in PPP (\$ billions) & 16,119 & 4,611 & 16,800 \\
& & & \\
\hline Nominal Per Capita GDP $(\$)$ & 6,700 & 38,550 & 53,104 \\
Per Capita GDP in PPP $(\$)$ & 10,940 & 36,260 & 53104 \\
\hline
\end{tabular}

Source: Economist Intelligence Unit estimates using World Bank PPP data.

Figure 3. Projections for Chinese and U.S. GDP on a PPP Basis: $\mathbf{2 0 0 0 - 2 0 3 0}$ 


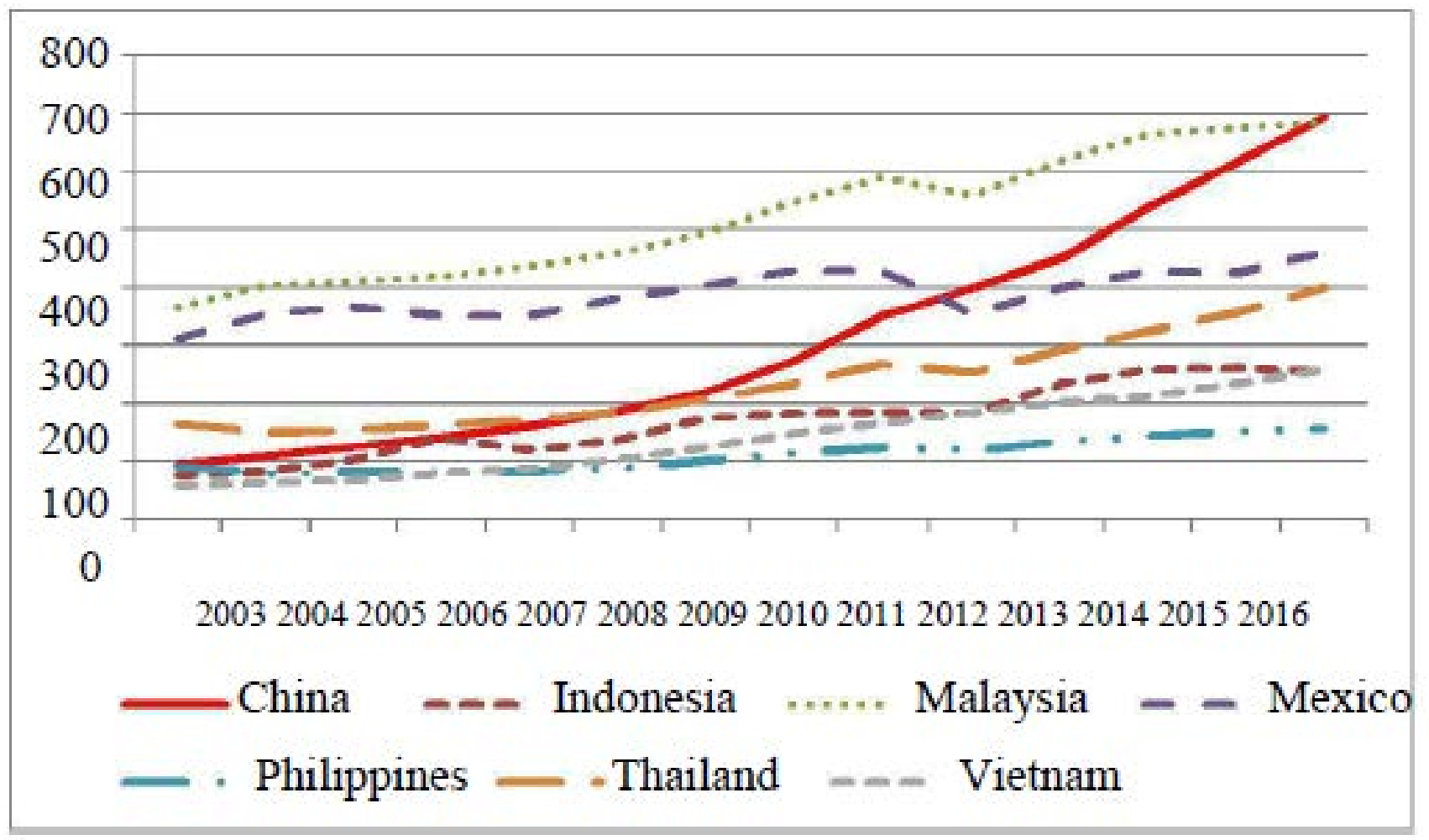

Source: Economist Intelligence Unit.

\subsubsection{China as the World's Largest Manufacturer}

China has appeared as the world's largest manufacturer according to the United Nations. Figure 4 lists figures out of the gross value added of manufacturing in China, the United States, and Japan expressed in U.S. dollars for 2004 to 2012. Gross expense added data provide the actual value of manufacturing that crop up in the country. These data show that China overtook Japan as the world's second-largest manufacturer on a gross value added basis in 2006 and the United States in 2010. In 2012 , the cost of China's manufacturing on a gross value added basis was $28.2 \%$ higher than that in the United States. Manufacturing plays a considerably more important role in the Chinese economy than it does for the United States and Japan. In 2011, China's gross valued added manufacturing was equal to $30.5 \%$ of GDP, compared to $12.3 \%$ for the United States and $18.7 \%$ for Japan. 
Figure 4. Gross Value Added Manufacturing in China, the United States, and Japan: 2004-2012 (\$ billions)

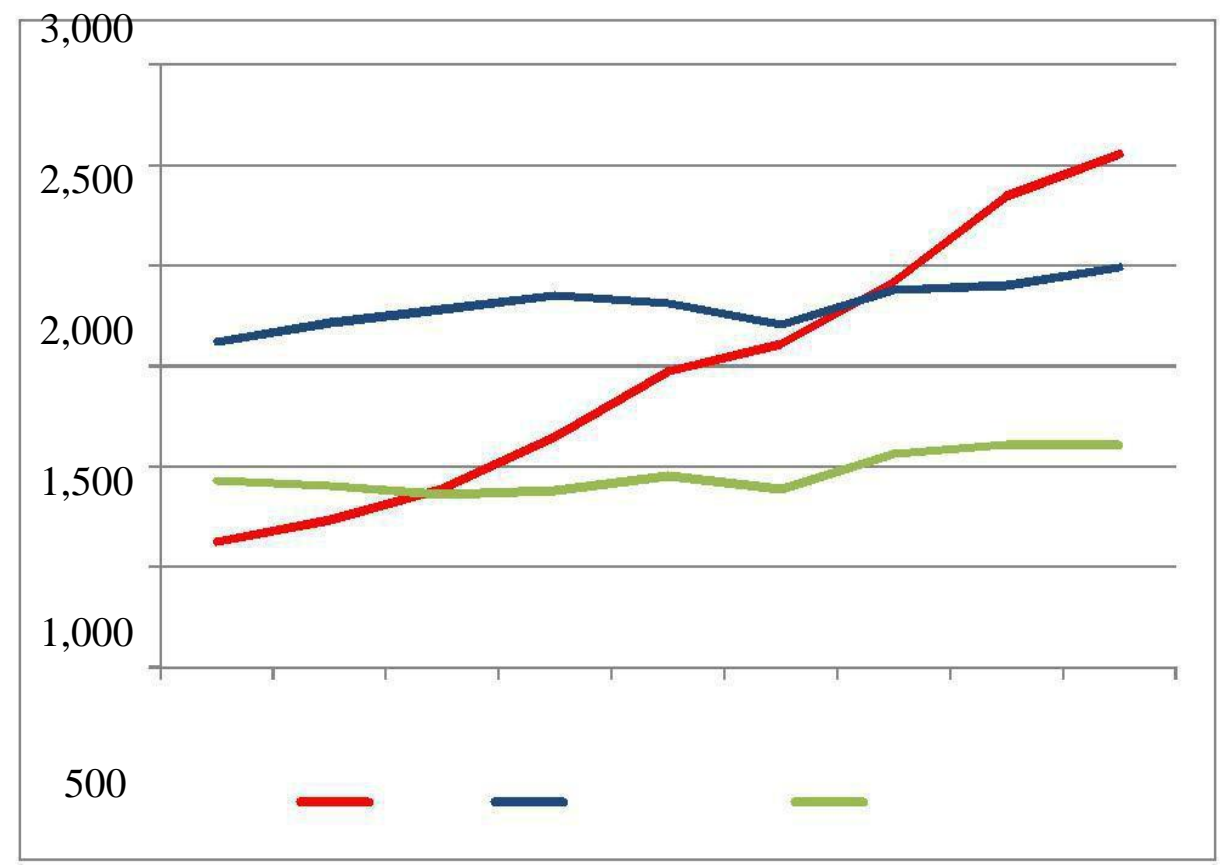

0

200420052006200720082009201020112012

China United States Japan

Source: United Nations, UN data.

\section{Changes in China's Wage Advantage}

China's large population and relatively low wage rates gave it a significant competitive benefit when economic readjustment and trade liberalization were first onset by the government in the late 1970s. However, this advantage emerges to be eroding as wages in China have increased in recent years. From 2003 to 2016, Chinese average real wages increased at an average annual rate of $11.4 \%$. As showed in Figure 5, China's average monthly wages in 2003 were $\$ 94$ compared with $\$ 311$ per month for Mexico. Despite, in 2016, China's average monthly wages at $\$ 694$ were $50.5 \%$ higher than those in Mexico (\$461). From 2003, China’s average wages were 92\% higher than those than Vietnam, but 
by 2016 , they were about $168 \%$ higher. Increasing labor expenditure are one of the major reasons why the Chinese state has focused on promoting the nation's innovation and productivity levels.

Figure 5. Average Monthly Wages for Selected Countries: 2003-2016

(U.S. dollars)

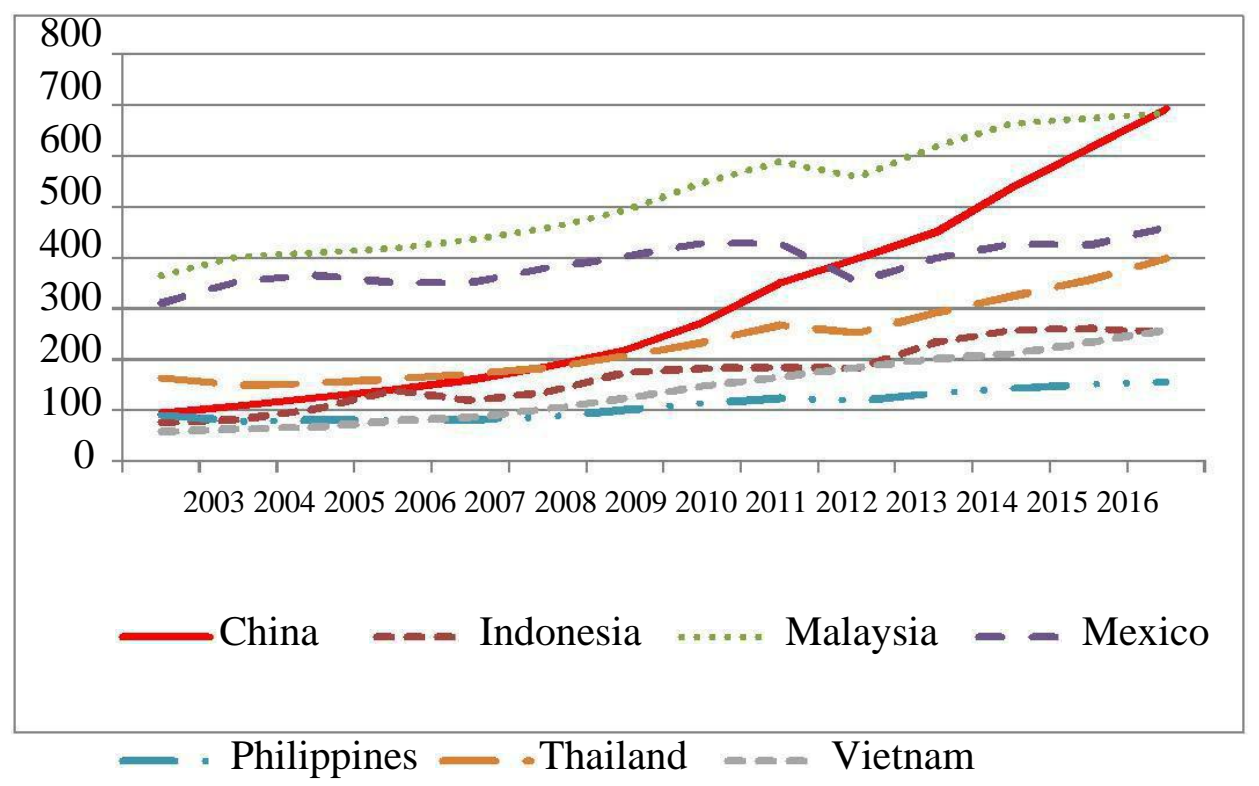

Source: Economist Intelligence Unit

\subsection{Foreign Direct Investment (FDI) in China}

China's trade and investment reforms and incentives force to a rise in FDI onset in the early 1990s. Such flows have been a main source of China's capacity profits and fast economic and trade growth. There were addressed about 445,244 foreign-invested enterprises 
registered in China in 2010, employing 55.2 million employees or $15.9 \%$ of the urban labor pool. As provided in Figure 6, FIEs account for a significant dividend of China's industrial profit. That level increased from $2.3 \%$ in 1990 to a high of $35.9 \%$ in 2003, but declined to $25.9 \%$ as of 2011. Further, FIEs are responsible for a significant level of China's foreign trade. In 2013, FIEs in China accounted for $47.3 \%$ of China's exports and $44.8 \%$ of its imports, however this level was down from its increase in 2006 when FIEs' share of Chinese exports and imports was 58.2\% and 59.7\%, respectively, as indicated in Figure 7. FIEs in China impact China's high technology exports. From 2002 to 2010, the share of China's high tech exports by FIEs peak from $79 \%$ to $82 \%$. During the same episode, the proportion of China's high tech exports by wholly owned foreign firms (which excludes foreign joint ventures with Chinese firms) rose from $55 \%$ to $67 \%$.

\section{Figure 6. Industrial Output by Foreign-Invested Firms in China as a Share of National Output Total: 1990-2011}

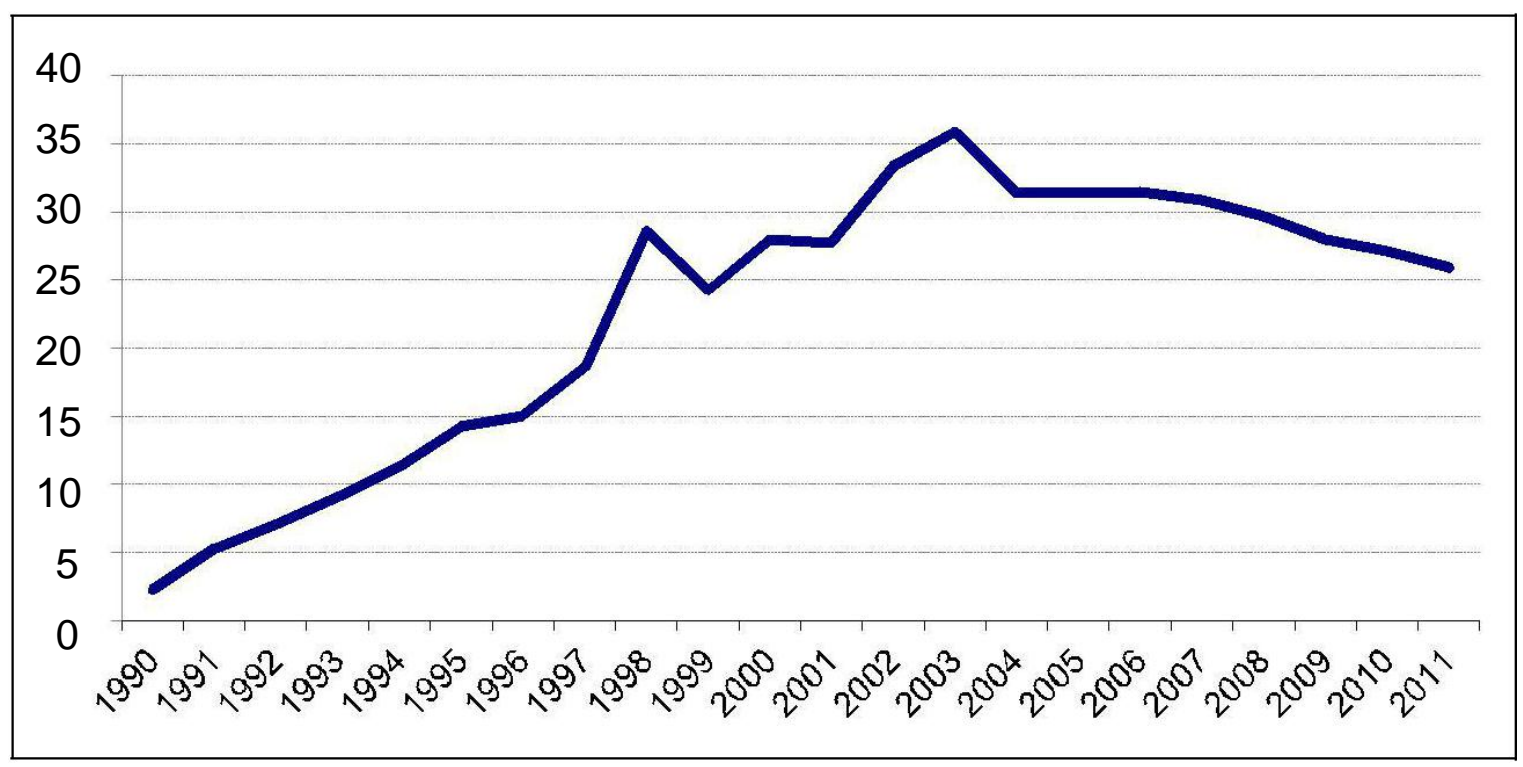


Figure 7. Proportion of China's Exports and Imports Attributed to Foreign-Invested Enterprises in China: 1990- 2014

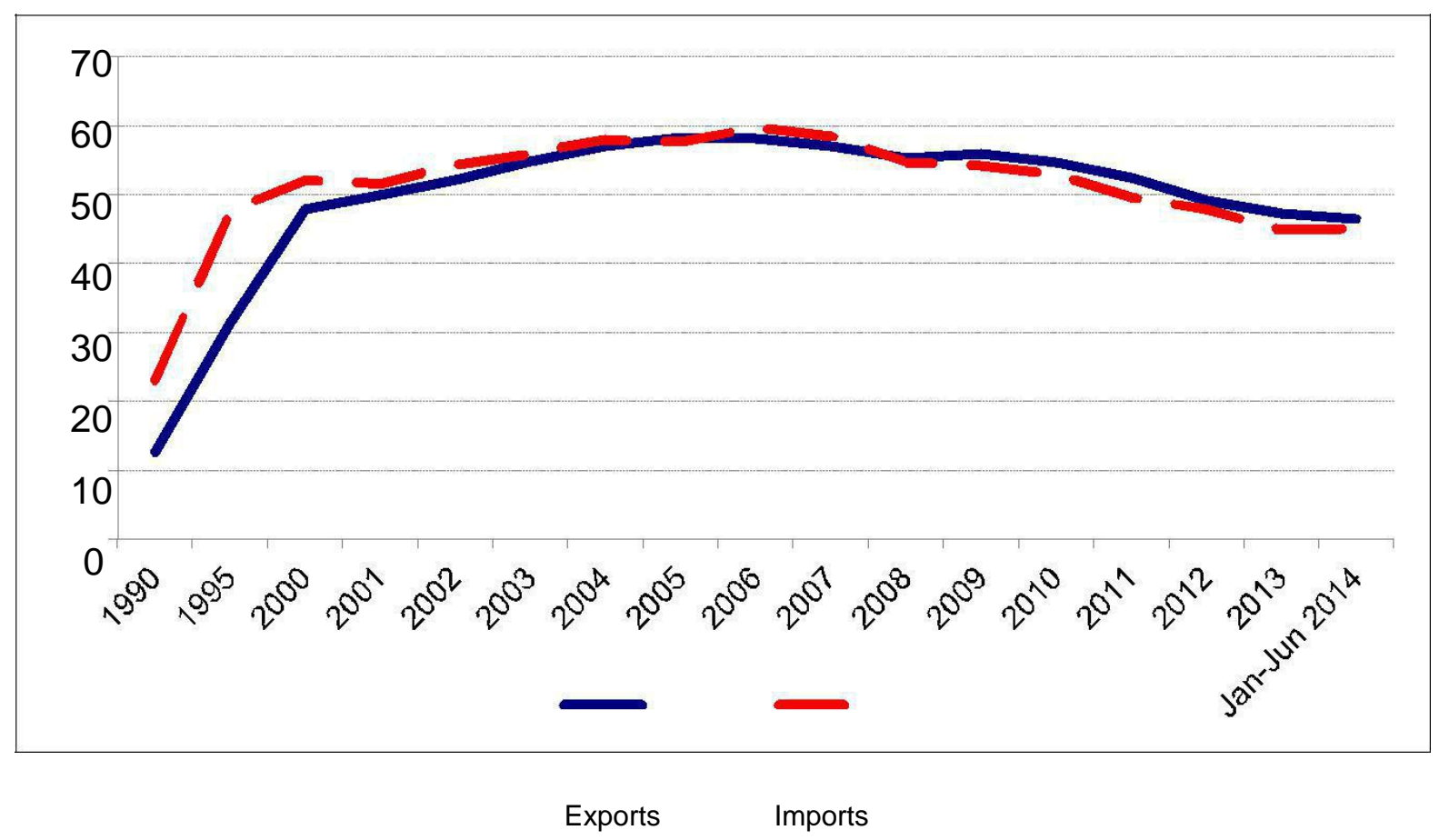

Source: Invest in China

According to the United Nations, annual FDI flows to China increased from \$2 billion 1989 to an estimated $\$ 121$ billion in 2015 (see Figure 8), and may have attained $\$ 127$ billion in 2015. The U.N. further evaluates the stock of FDI in China through 2014 at $\$ 832.9$ billion. As point out in Figure 9, China was the world's second-largest target for FDI flows in 2015. According to Chinese state data on non-financial FDI inflows, the biggest sources of cumulative FDI in China for 2009-2015 were Hong Kong (47.0\%), the British Virgin Islands (BVI), Japan, the United States, and Taiwan (see Table 2). The biggest sources of non-financial FDI inflows into China in 2015 were Hong Kong (67\% of total), Singapore, Japan, Taiwan, and the United States. According to Chinese data, annual U.S. In 2015, they were $\$ 3.4$ billion or $2.9 \%$ of total FDI flows to China (see Figure 10). The stock of U.S. non-financial FDI in China was \$74.6 billion over 2015. 
Figure 8. Annual FDI Flows to China: 1989-2015

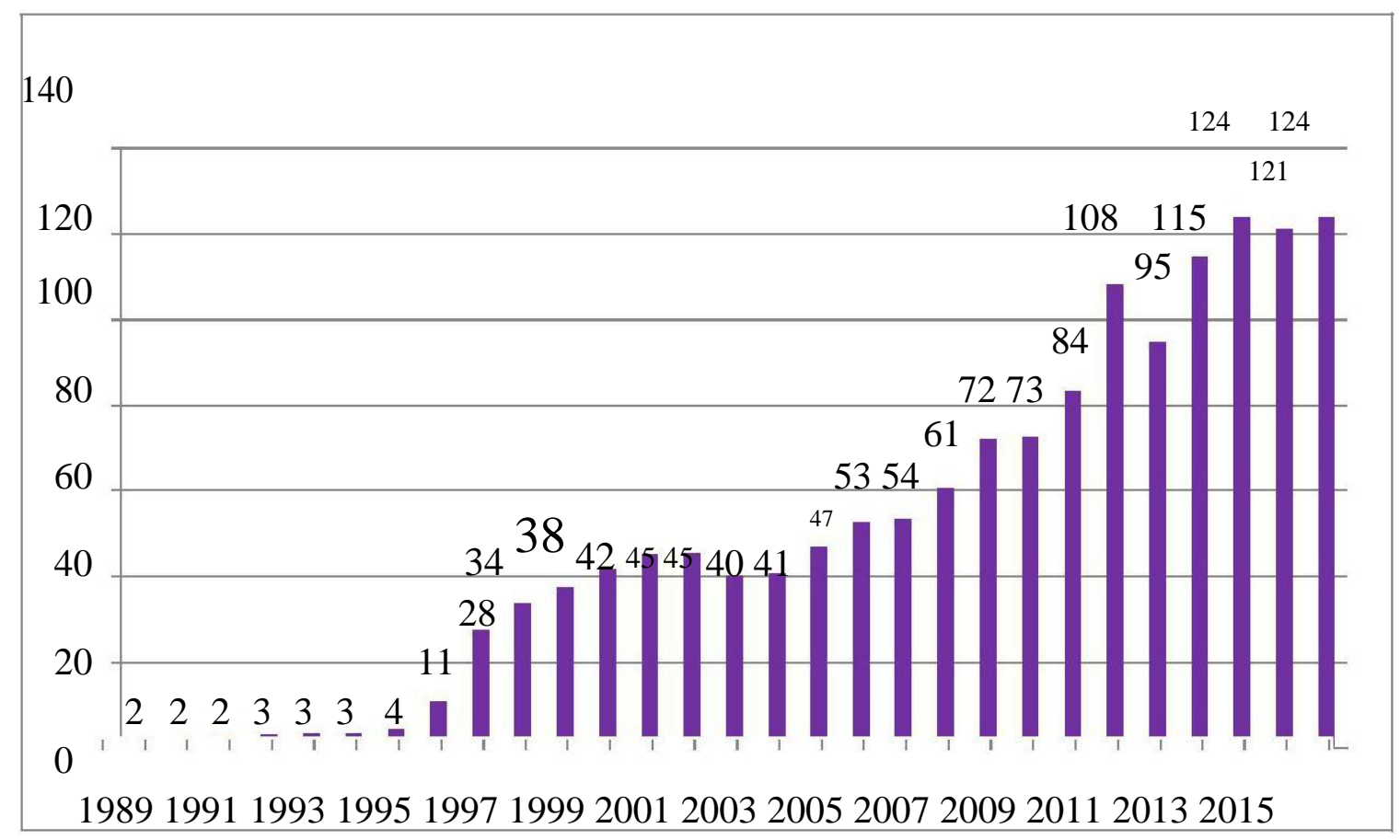

Source: The United Nations 


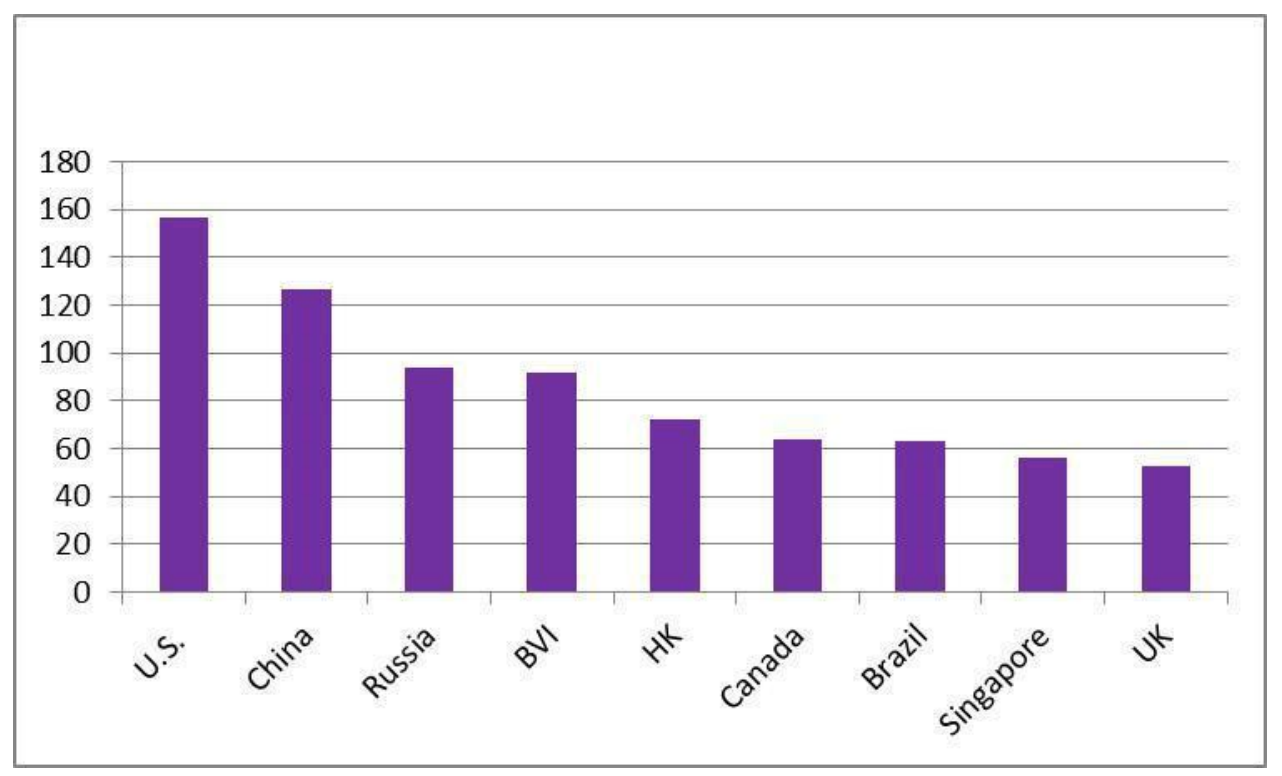

Figure 9. Biggest Recipients of Global FDI Inflows in 2015

Source: United Nations Conference on Trade and Investment. 
Table 2. Chinese Data on Main Sources of FDI Flows to China: 1979-2015

( $\$$ billions and percentage of total)

\begin{tabular}{|c|c|c|c|c|}
\hline \multirow[b]{3}{*}{ Country } & \multirow{2}{*}{\multicolumn{2}{|c|}{$\begin{array}{l}\text { Estimated Cumulative Utilized } \\
\text { FDI: } 1979-2015\end{array}$}} & \multirow{2}{*}{\multicolumn{2}{|c|}{ Utilized FDI in 2015}} \\
\hline & & & & \\
\hline & Amount & $\%$ of Total & Amount & $\%$ of Total \\
\hline Total & $1,453.3$ & 100.0 & 117.6 & 100.0 \\
\hline Hong Kong & 682.8 & 47.0 & 78.3 & 66.6 \\
\hline British Virgin Islands* & 111.8 & 7.7 & NA & NA \\
\hline Japan & 94.4 & 6.5 & 7.1 & 6.0 \\
\hline United States & 74.6 & 5.1 & 3.4 & 2.9 \\
\hline Taiwan & 70.1 & 4.8 & 5.2 & 4.4 \\
\hline Singapore & 67.2 & 4.6 & 7.3 & 6.2 \\
\hline South Korea & 56.1 & 3.9 & 3.1 & 2.6 \\
\hline
\end{tabular}

Source: Chinese Ministry of Commerce and Chinese Statistical Yearbook. 
Figure 10. Chinese Data on Annual U.S. FDI Flows to China: 1985-2013

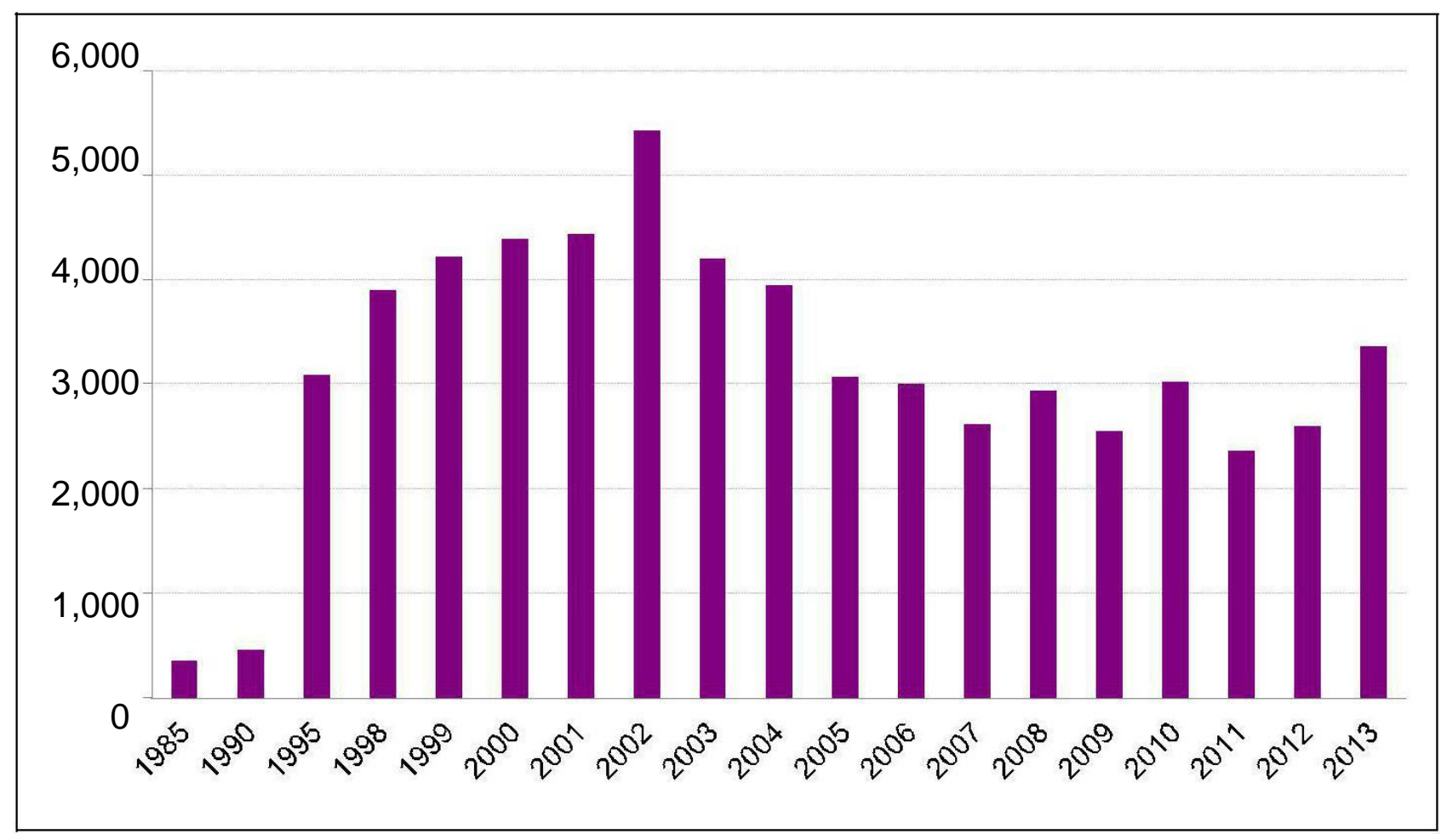

Source: Chinese Ministry of Commerce and Chinese Yearbook, various years.

\subsubsection{China's Rising FDI Outflows}

A major point of China's economic modernization and growth approach in 1980s and 1990s was to promote FDI into China to help improve the development of domestic companies. Investment by Chinese firms overseas was restricted. However, during 2000, China's leaders onset a new "go global" approach, which sought to boost Chinese firms to invest overseas. One major factor conducting this investment is China's massive accumulation of foreign exchange assets. Traditionally, a significant level of those reserves has been invested in relatively secure, but low-yielding, stocks, for instance U.S. Treasury 
securities. The CIC was originally funded at \$200 billion, making it one of the world's biggest sovereign wealth reserves. Further factor behind the government's conduct to improve more external FDI flows has been to achieve natural resources, for example oil and minerals, deemed by the Chinese government as necessary to help China's fast economic rise. Definitely, the Chinese government has announced its goal of developing globally ambitious Chinese companies with their own products and goods. Devoting in foreign firms, or acquiring them, is illustrated as an approach for Chinese state.

Companies to access technology, management improvement, and often, internationally recognized brands, needed to support Chinese firms become more globally competitive or ambitious. For instance, Gunby, P., Jin, Y et al.(2017) found that foreign direct investment (FDI) has been linked to economic growth in a number of countries. Productivity spillovers at the firm level have been identified as a key element in the process by which FDI stimulates economic growth. Moreover, there is evidence of FDI-related productivity spillovers in China. A recent study by Ning, Y et al.(2017) measures monthly short-term international capital flows during Jan. 2000 to Jul. 2015 in China. It is shown that, since mid-2014 the amount of short-term international capital outflows in China has increased rapidly, reaching the historical peak at 65.8 billion dollars per month in July, 2015.

China has become a significant source of global FDI outflows, which, according to the U.N. Increased from \$ 2.7 billion in 2002 to \$101 billion in 2013 (see Figure 11). China ranked as the third-biggest source of global FDI in 2013. The reserve of China's outward FDI over 2013 is evaluated at \$512 billion. China's FDI outflows by destination for 2015 are provided in Table 3. These data show that the largest target of total Chinese FDI over 2015 were Hong Kong with 58.6\% of total, the BVI, the Cayman Islands, the United States, and Australia. In terms of Chinese FDI flows in 2015, the largest recipients were Hong Kong with, the United States, Kazakhstan, the United Kingdom, and the British Virgin Islands.

Table 3. Main Destinations of Chinese Overseas Direct Investment in 2015:

Flows and Stock ( $\$$ billions) 
Hong Kong

British Virgin Islands

Cayman Islands

United States

Australia

Singapore

Luxembourg
51.2

2.2

0.8

4.0

2.2

1.5

1.1
306.4

30.9

30.1

17.1

13.9

12.4

9.0
58.6

5.8

5.7

3.3

2.6

2.3

1.7

Source: Chinese Ministry of Commerce.

Figure 11. China's Annual FDI Outflows: 2000-2013

(\$ billions)

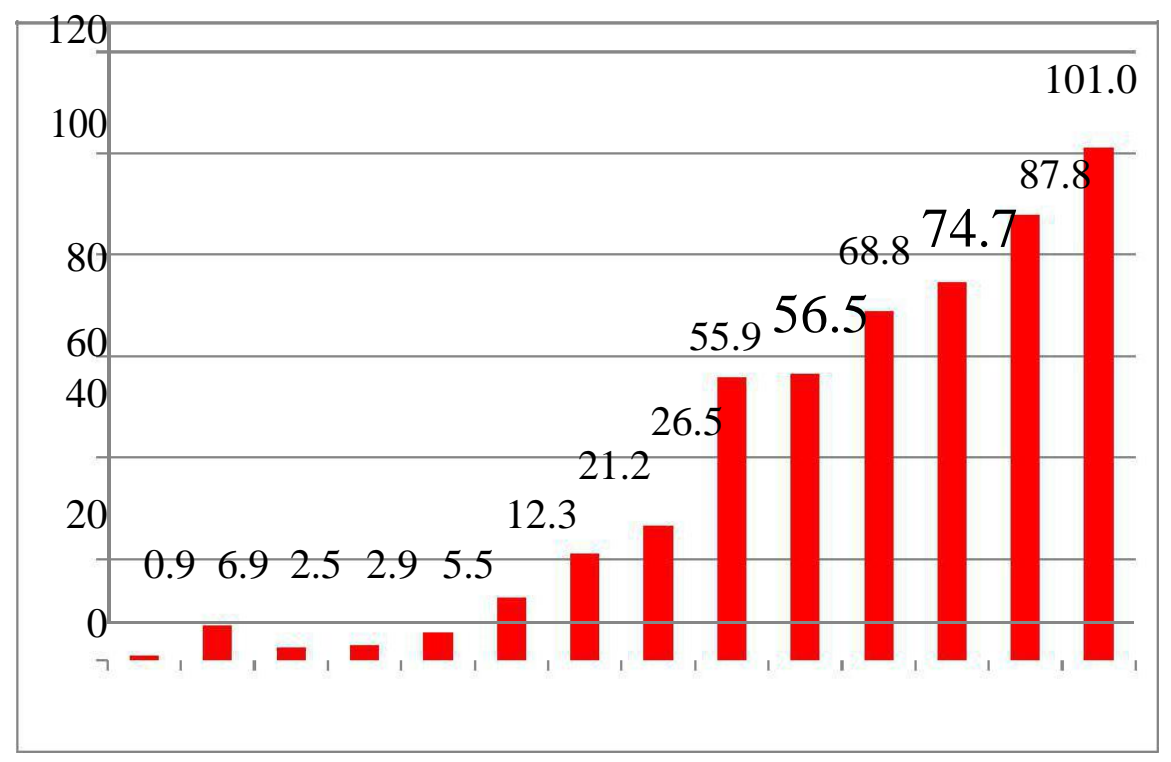

20002001200220032004200520062007200820092010201120122013

Source: Chinese Ministry of Commerce 2013 


\section{China's Commodity Trade Patterns}

Economic reforms, trade and investment liberalization have supported transform China into a major trading power. Chinese commodity exports increased from \$14 billion in 1979 to $\$ 2.2$ trillion in 2013 , while products imports increased from $\$ 18$ billion to $\$ 1.9$ trillion (see Table 4 and Figure 12).

From 1990 to 2013, the annual rise of China's exports and imports averaged $18.5 \%$ and 17.3\%, respectively ( Figure 13). China's exports and imports in 2013 increased by 7.8\% and $7.3 \%$, properly. In the first half of 2014 , China's exports and imports grew by $0.9 \%$ and $1.7 \%$ over same period in 2013. China's goods trade excess grew sharply from 2004 to 2008 , rising from $\$ 32$ billion to $\$ 297$ billion. That surplus fell each year from 2009 to 2011, dropping to $\$ 158$ billion. However, in 2012, China's trade residue rose to $\$ 233$ billion, and in 2013 it increased to $\$ 261$ billion.

During 2009, China overtook Germany to become both the world's biggest commodity exporter and the second-largest goods importer. In 2012, China exceeded the United States as the world's largest commodity trading economy. As provided in Figure 14, China's dividend of global merchandise exports more than tripled from 2000 to 2013, increasing from $3.8 \%$ to $12.1 \%$, according to the World Bank this figure could rise to $20 \%$ by 2030 . Commodity trade excesses, huge-scale foreign expenditure, and large

purchases of foreign currencies to consolidate its exchange rate with the dollar and further currencies have enabled China to become by far the world's biggest buyer of foreign exchange founds at approximately \$3.9 trillion as of March 2014.

Table 4. China's Commodity World Trade: 1979-2014

( $\$$ billions)

\begin{tabular}{cccc}
\hline Year & Exports & Imports & Trade Balance \\
\hline 1979 & & & \\
1980 & 13.7 & 15.7 & -2.0 \\
& 18.1 & 19.5 & -1.4
\end{tabular}




\begin{tabular}{rrrr}
1985 & 27.3 & 42.5 & -15.3 \\
1990 & 62.9 & 53.9 & 9.0 \\
1995 & 148.8 & 132.1 & 16.7 \\
2000 & 249.2 & 225.1 & 24.1 \\
2001 & 266.2 & 243.6 & 22.6 \\
2002 & 325.6 & 295.2 & 30.4 \\
2003 & 438.4 & 412.8 & 25.6 \\
2004 & 593.4 & 561.4 & 32.0 \\
2005 & 762.0 & 660.1 & 101.9 \\
2006 & 969.1 & 791.5 & 177.6 \\
2007 & $1,218.0$ & 955.8 & 262.2 \\
2008 & $1,428.9$ & $1,131.5$ & 297.4 \\
2009 & $1,202.0$ & $1,003.9$ & 198.2 \\
2010 & $1,578.4$ & $1,393.9$ & 184.5 \\
2011 & $1,899.3$ & $1,741.4$ & 157.9 \\
2012 & $2,050.1$ & $1,817.3$ & 232.8 \\
2013 & $2,210.7$ & $1,949.3$ & 261.4 \\
2014 (est.) & $2,230.6$ & $1,982.4$ & 248.2 \\
\hline
\end{tabular}

Source: Global Trade Atlas.

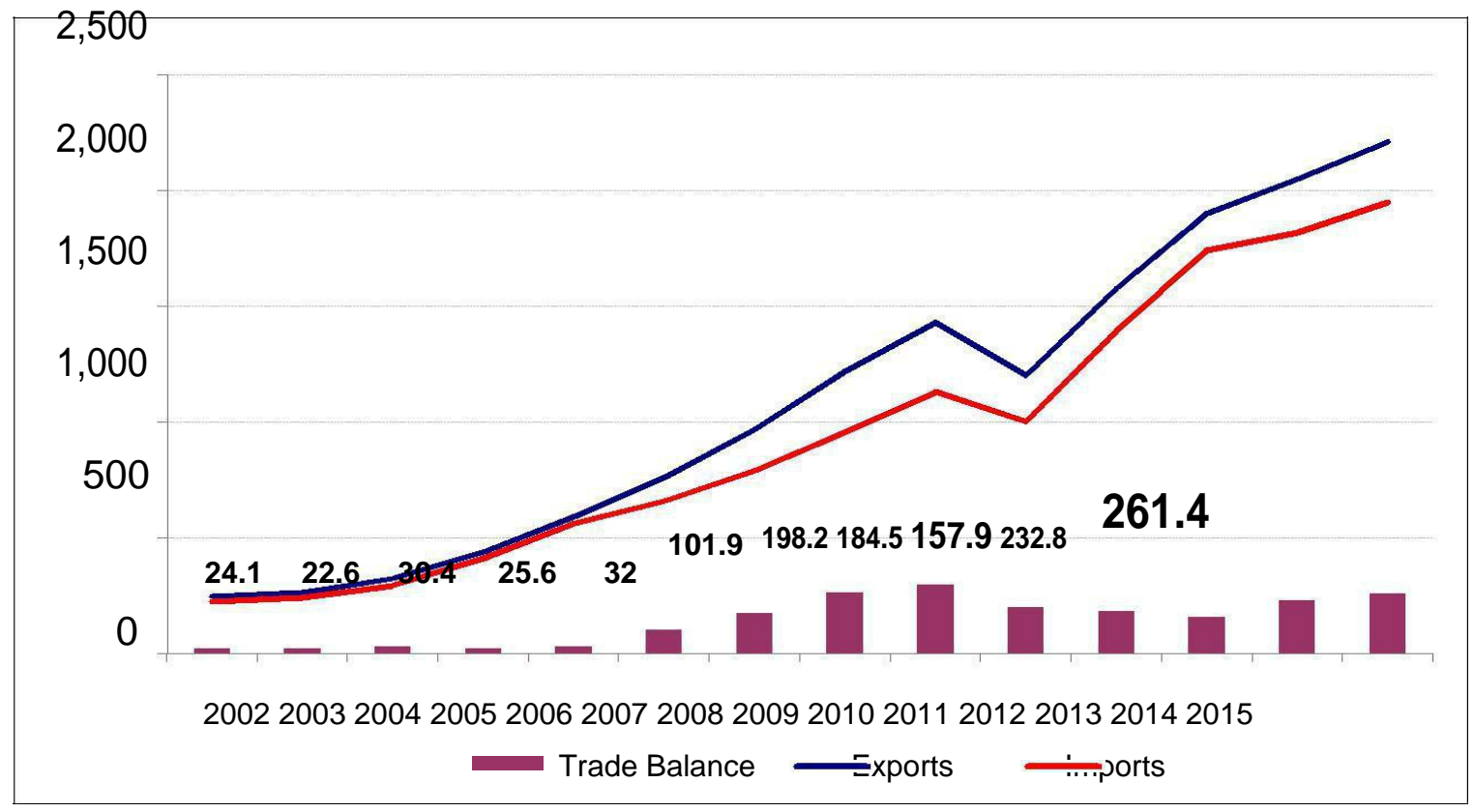

Source: World Trade Atlas.

Figure 12. China's Commodity Trade: 2002-2015 (\$ billions) 
Figure 13. Annual Change in China's Merchandise Exports and Imports: 1990-2014

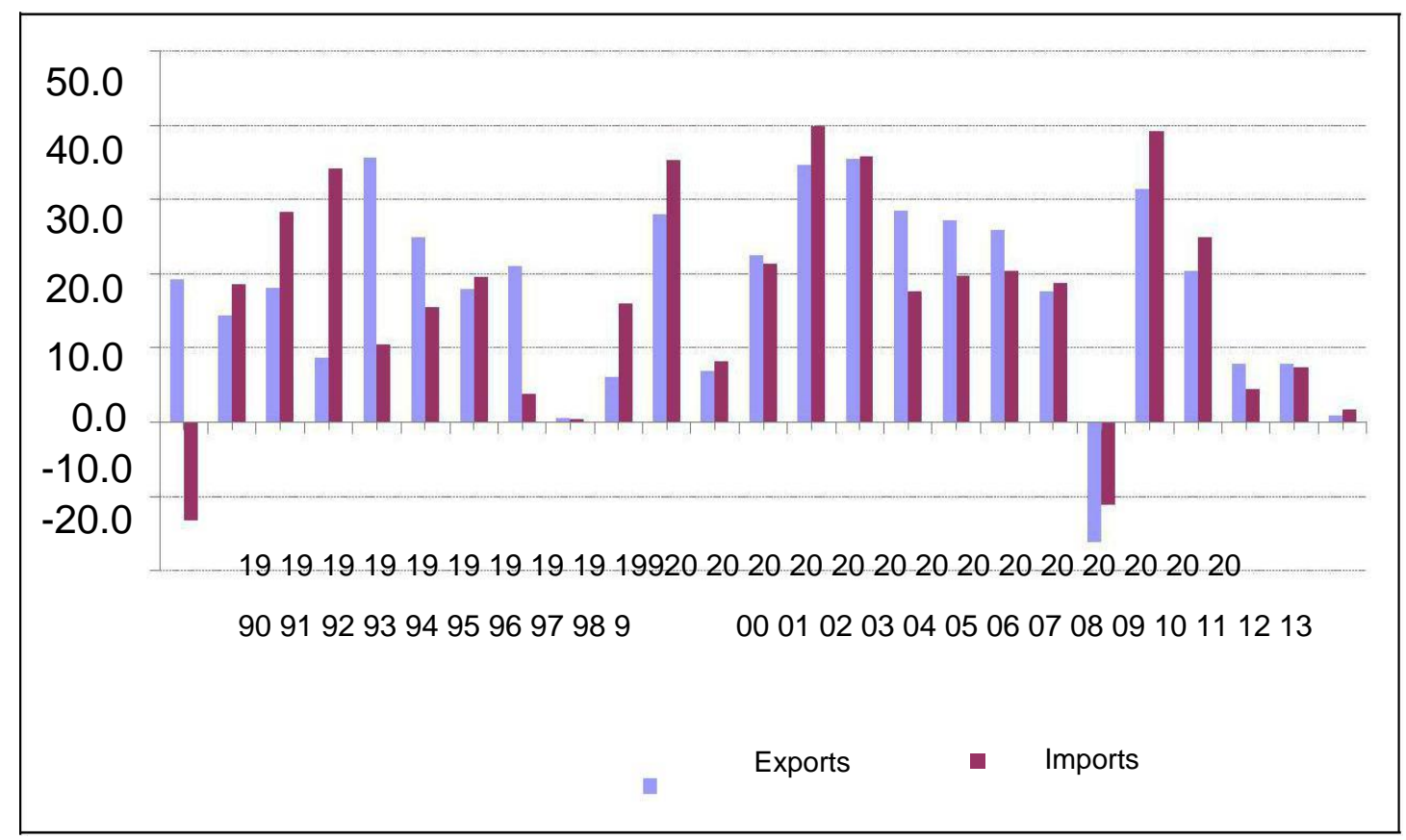

Source: Global Trade Atlas using official Chinese data. 
Figure 14. China's Share of Global Merchandise Exports: 1990-2013

(\$ billions)

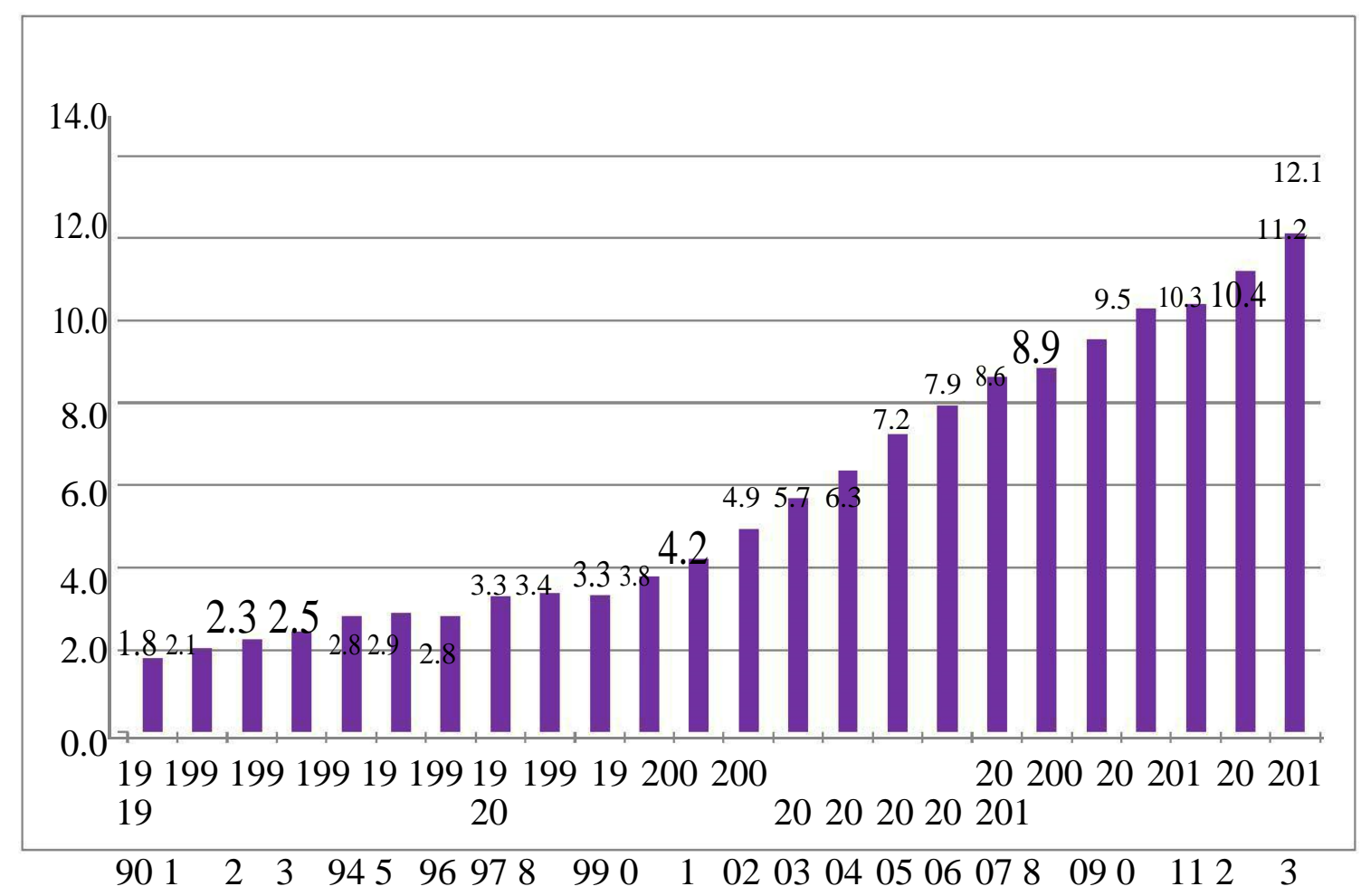

Source: Economist Intelligence Unit. 


\subsection{China's Major Trading Partners}

Table 5 shows official Chinese trade data on its main trading partners in 2015, which combined the countries that compose the European Union, the United States, the 10 nations that constitute the Association of Southeast Asian Nations, and Japan (ASEAN). China's top three export retails were Hong Kong, the United States, and the European Union (EU), while its significant sources for imports were the EU, ASEAN, and South Korea. According to Chinese data, it consolidated huge trade excess with Hong Kong, the United States, and the EU, and provided huge trade imbalances with Taiwan (-\$107 billion) and South Korea (-\$95 billion). China's trade data differ from those of many of its trading partners. These differences emerge to be largely caused by how China's trade via Hong Kong is counted in official Chinese trade data. China treats a large proportion of its exports over Hong Kong as Chinese exports to Hong Kong for statistical aims, while a lot of countries that import Chinese goods through Hong Kong generally attribute their cause to China for statistical objective, combining the United States.

Table 5. China's Main Trading Partners in 2015

(\$ billions)

\begin{tabular}{lcccc}
\hline \multicolumn{1}{c}{ Country } & Total Trade & $\begin{array}{c}\text { Chinese } \\
\text { Exports }\end{array}$ & $\begin{array}{c}\text { Chinese } \\
\text { Imports }\end{array}$ & $\begin{array}{c}\text { China's Trade } \\
\text { Balance }\end{array}$ \\
\hline European Union & 559 & 339 & 220 & 119 \\
United States & 514 & 368 & 146 & 222 \\
ASEAN & 443 & 244 & 199 & 45 \\
Hong Kong & 401 & 385 & 16 & 369 \\
Japan & 312 & 150 & 162 & -12 \\
South Korea & 274 & 91 & 183 & -95 \\
Taiwan & 198 & 41 & 157 & -107 \\
Total Chinese Trade & $\mathbf{4 , 1 6 0}$ & $\mathbf{2 , 2 1 1}$ & $\mathbf{1 , 9 4 9}$ & $\mathbf{2 6 2}$ \\
\hline
\end{tabular}

Sources: Global Trade Atlas and World Trade Atlas. 


\subsubsection{Main Chinese Trade Merchandises}

China's large of low-cost labor has made it internationally ambitious in different low-cost, labor-deep manufactures. As issues, manufactured commodities constitute a significant dividend of China's market. A substantial extent of China's imports is constituted of parts and inherent that are assembled into finished commodities, for instance consumer electronic products and computers, and then exported. Usually, the value-added to such products in China by Chinese workers is relatively small compared to the total expense of the product when it is exported overseas.

China's major 10 exports and imports are listed in Table 6 and Table 7, respectively, applying the harmonized cost scheme on a two-digit level. Main exports included electrical machinery, machinery, knit apparel, and furniture and bedding while major imports incorporated electrical machinery, mineral fuel, machinery, and ores. 
Table 6. Main Chinese Exports: 2015

\begin{tabular}{|c|c|c|c|c|}
\hline HS Code & Description & $\$$ billions & $\begin{array}{c}\text { Percentage } \\
\text { of Total }\end{array}$ & $\begin{array}{l}2014 / 2013 \\
\% \text { Change }\end{array}$ \\
\hline & World & 2,201 & 100.0 & 7.8 \\
\hline 84 & Electrical machinery & 562 & 25.4 & 15.2 \\
\hline 82 & Machinery & 393 & 17.3 & 1.9 \\
\hline 64 & Knit apparel & 86 & 5.4 & 10.3 \\
\hline 84 & Furniture and bedding & 86 & 3.9 & 11.1 \\
\hline 80 & Optical, photographic, cinematographic, measuring & 78 & 4.4 & 2.3 \\
\hline 70 & checking, precision, medical or surgical instruments & & & \\
\hline 88 & and apparatus; parts and accessories thereof & & & \\
\hline 64 & Woven apparel & 69 & 3.6 & 12.5 \\
\hline 38 & Plastics & 63 & 3.8 & 10.7 \\
\hline 86 & Vehicles, except railway (mainly auto parts, motorcycles, & 60 & 3.7 & 5.2 \\
\hline 79 & trucks, and bicycles) & & & \\
\hline 76 & Iron and steel products & 58 & 2.8 & 3.1 \\
\hline 61 & Footwear & 61 & 2.6 & 7.6 \\
\hline
\end{tabular}

Source: World Trade Atlas, using official Chinese statistics.

Table 7. Major Chinese Imports: 2015

( $\$$ billions)

\begin{tabular}{|c|c|c|c|c|}
\hline HS Code & Description & \multirow{2}{*}{$\begin{array}{r}\text { \$ billions } \\
1,859\end{array}$} & \multirow{2}{*}{$\begin{array}{c}\text { Percentage of } \\
\text { Total } \\
100.0\end{array}$} & \multirow{2}{*}{$\begin{array}{r}2014 / 2013 \\
\% \text { change } \\
8.3\end{array}$} \\
\hline & World & & & \\
\hline 85 & Electrical machinery & 439 & 22.5 & 16.1 \\
\hline 27 & Mineral fuel, oil etc. & 324 & 16.1 & 0.7 \\
\hline 84 & Machinery & 161 & 8.8 & -6.1 \\
\hline 26 & Ores, slag, and ash & 138 & 7.6 & 10.1 \\
\hline 90 & $\begin{array}{l}\text { Optical, photographic, cinematographic, measuring, } \\
\text { checking, precision, medical or surgical instruments } \\
\text { and apparatus; parts and accessories thereof }\end{array}$ & 118 & 5.5 & 1.2 \\
\hline \multirow[t]{2}{*}{98} & Special Classification & 125 & 4.4 & 52.1 \\
\hline & & 84 & 3.8 & 5.0 \\
\hline
\end{tabular}


70

3.7

29 Organic chemicals

62

2.4

8.3

74 Copper and articles thereof

52

3.6

$-6.7$

Source: World Trade Atlas, using official Chinese statistics.

\section{Dependence on Exporting and Fixed Investment}

According to a report by IMF, fixed investment associated to trade commodities plus net exports together accounted for over 60\% of China's GDP rise from 2001 to 2008, which was significantly higher than in the G -7 countries about $16 \%$, the euro zone (30\%), and the rest of Asia (35\%). As provided in Figure 15, from 1990 to 2013, Chinese gross savings as a percent of GDP and gross fixed expenditure as a percent of GDP both increased significantly, while private consumption as a percent of GDP decreased sharply. Further, as figure out in Figure 16, personal disposable income in China as a proportion of GDP was lower in $2013(43.9 \%)$ than it was in 2000 (47.9\%). China's gross savings as a percent of GDP and gross fixed asset as a percent of GDP are the highest between any of the world's biggest economies, although China's private consumption as a share of GDP is the lowest.

A lot of scholars argued that the falling proportion of private consumption and disposable income relative to GDP is largely caused by two major factors for instance, China's banking policies and the lack of an adequate social safety net. The Chinese government brings restrictions on the export of capital. As a result, Chinese investors put a huge proportion of their savings in domestic banks. The Chinese government sets the interest rate on securities. Usually this quota is under the proportion of inflation, which lowers investor income. Some economists suggest this policy to compose a relocation of wealth from Chinese investors to Chinese companies which profit from low interest rates. This "cost" on investor income negatively impacts household consumption. Secondly, China's 
shortage of an adequate social safety net for example pensions, health care, unemployment insurance, and education induces investors to secure a significant part of their livelihood.

Chinese economic policies have issued in gross fixed investment being the major instrument of the country's economic growth for every year from 2000 to 2013.

(In 2011 gross fixed investment and private consumption each accounted for 3.0 percentage points; Figure 15).

Figure15. Chinese Gross Savings, Gross Fixed Investment, and Private Consumption as a Percent of GDP: 1990-2013

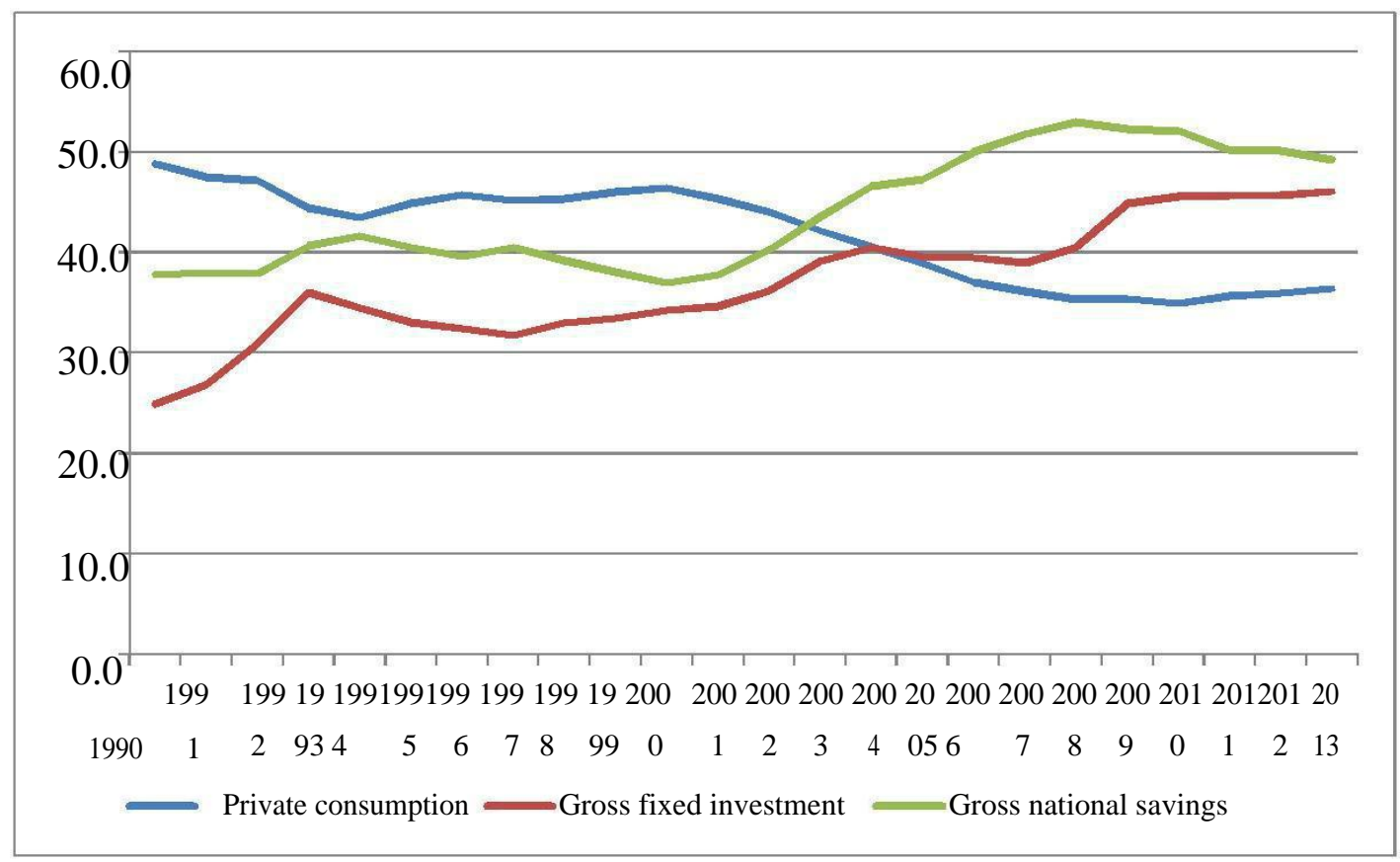

Source: Economist Intelligence Unit. 
Figure 16. Chinese Disposable Personal Income as a Percent of GDP: 2000-2013

(percent)

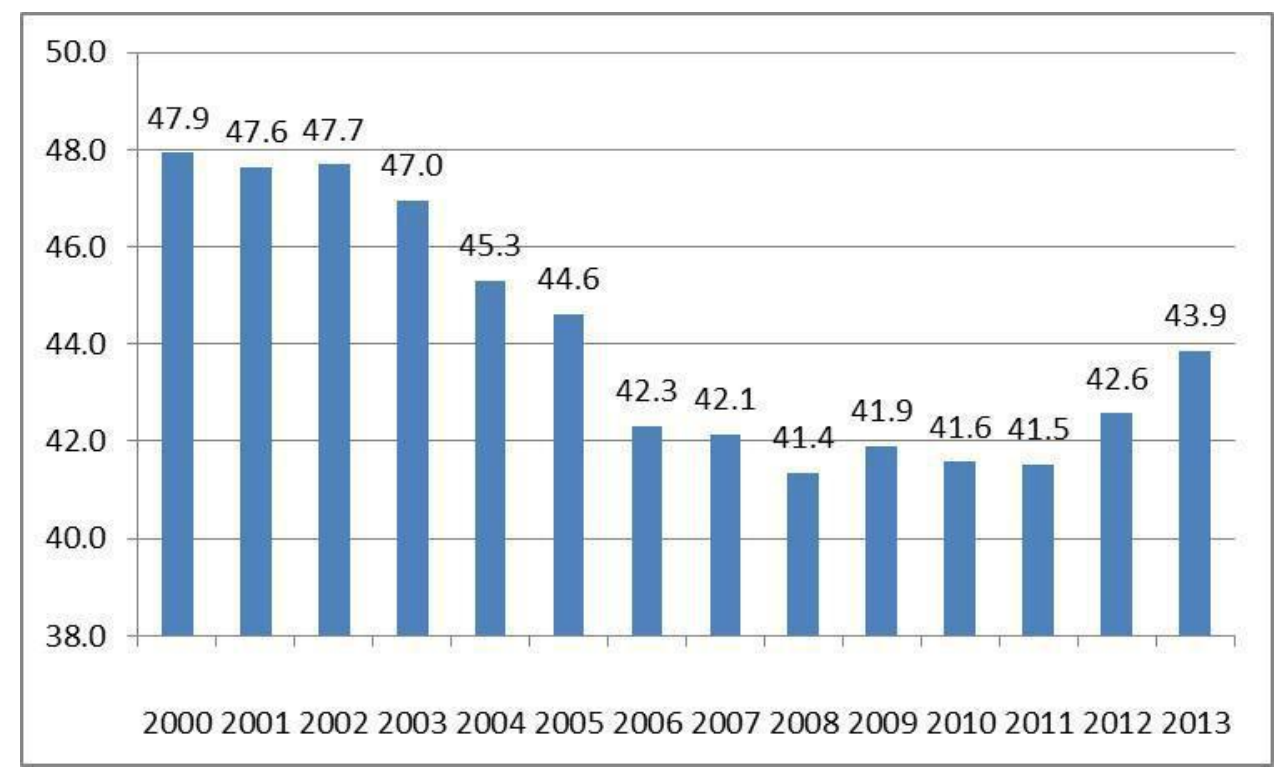

Source: Economist Intelligence Unit. 
Figure 17. Sources of Chinese GDP Growth: 2010-2016

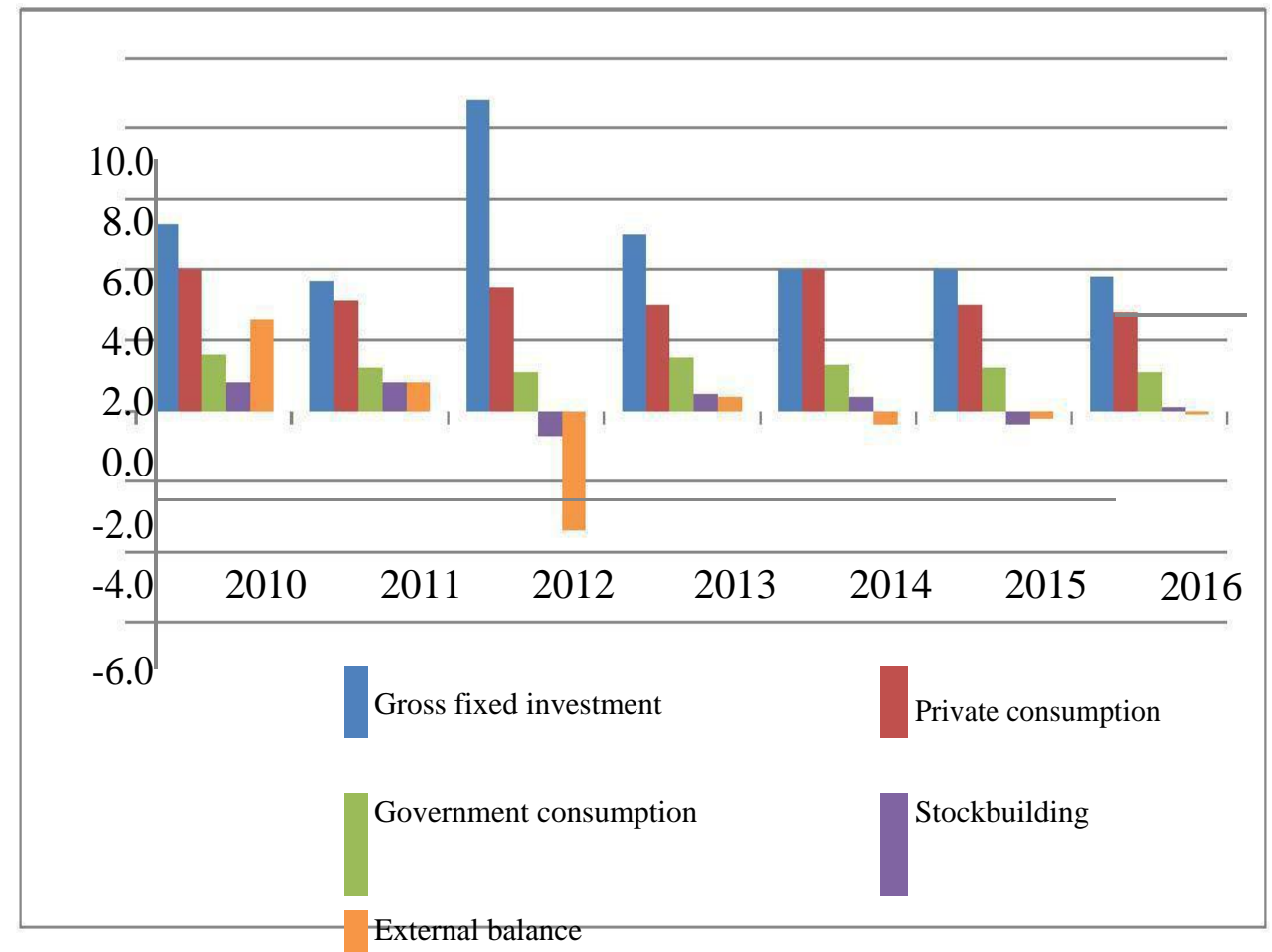

Source: Economist Intelligence Unit.

\subsection{Structural economic reforms}

A lot of government officials have publicly stated the need for China to approach from its traditional economic growth model of growth at all cost to one that balances economic rise with a number of social goals in order to improve a "socialist harmonious society," and to further modernize the economy. Yu, H. (2017) points out that the 'One Belt, One Road' (OBOR) initiatives form the centerpiece of the Chinese leadership's new foreign policy. The OBOR initiatives are a reflection of China's ascendance in the global arena, economically, politically, and strategically. Developing inter-connectivity of infrastructure development forms a central part of China's OBOR initiatives. 
Suzuki, T. (2017) shows that up until now, the Renminbi (RMB) reform has been progressing gradually. With the RMB becoming a Special Drawing Right (SDR) component currency, China's monetary policies will exert significant influence on the international marketplace. The year 2014 witnessed the weakening of the RMB against the U.S. dollar, yet thanks to China's prudent economic policies, the RMB stopped depreciating further and remained quite stable for the first half of 2015, which benefited not only China itself, but also the United States, Japan, and other Asian economies.

According to Basu, D et al.(2015) the Chinese economic reforms and the Soviet (during Gorbachev) and Russian economic failures have attracted worldwide attention because a number of countries in the developing world and various Eastern European countries have been implementing the same type of economic reforms and structural adjustments, supported by international financial institutions like the World Bank, the IMF, and the EBRD. It is an important question as to what lessons we can learn from this. Although Yeltsin, immediately after the destruction of the old Soviet Union, implemented the structural adjustment program, commonly known as 'shock therapy,' it was Gorbachev who initiated the process and tried to build the necessary institutional structures. Similarly, although Deng in China is known as the architect of the Chinese reform process it was Mao Tse-tung himself who, after the failure of the Cultural Revolution of 1966-1976, initiated the reforms in agriculture and land ownership in China that later developed into the so-called Chinese-style reform process.

A study by Curtis, C. C. (2016) also investigates the impact of economic reforms on China's growth in total factor productivity (TFP). The author builds a model with two sectors in production - the private and the state sectors - that features capital market imperfections on the private sector. Following the removal of prohibitive barriers to private entrepreneurship (reforms), TFP gains follow the expansion of the private sector and the closure of the least productive state enterprises. Although the distribution of production technologies in both sectors is identical, the model generates persistently higher TFP in the private sector via a selection mechanism arising from financial frictions.

Further, Nagaraj, R. (2017) suggests that manufacturing output grew 7\%-8\% annually since 1991, with a marked improvement in the variety and quality of goods produced. Yet, 
its share in gross domestic product has practically stagnated, with a sharp rise in import intensity. Liberal (or market-friendly) policies were expected to boost labour intensive exports and industrial growth. However, this may not use in certain areas. For instance, the transition from planned to retail economy has involved a significant shift of financial liability from state-owned firms to investors, thereby creating a huge perceived need for precautionary securing by investors to resource anticipated retirement, medical and educational cost. High saving has become a main source of imbalance in the macro economy. While this type of policies has been successful in boosting rise and productivity for a sustained period, the limitations of such policies were not properly understood between policy analysts.

\subsubsection{External policies}

Many scholars for example Shen, W. (2016) points out that as the world's largest greenhouse gas (GHG) polluter, China's annual emissions accounted for almost 30 per cent of the world's total emissions in 2014 - more than the United States (15 per cent) and the European Union (10 per cent) combined (World Bank 2015). China's efforts to curb its soaring emissions will play a decisive role in containing temperature rise and in preventing the catastrophic consequences of climate change. In recent years, the Chinese government has paid greater attention to climate change. President Xi Jinping's attendance at the COP21 conference in Paris was a first by a Chinese leader. Before the conference, China's climate officers submitted the country's Intended Nationally Determined Contributions to the UN Framework Convention on Climate Change as its formal commitment to the international community to control its GHG emissions.

An investigation by Weiss, J. C et al.(2016) suggests that trade imbalances have often led to accusations of "currency manipulation" and efforts to remedy the purported effects of exchange rate misalignment. This paper investigates the impact of US pressure on China to revalue the RMB. Using vector auto-regression (VAR) to analyze an original data-set of US statements and actions between 2005 and 2012, we examine the over-time dynamics between US pressure and the nominal RMB/USD exchange rate. A case study of mounting US pressure in advance of the 2010 midterm election illustrates China's responsiveness in timing adjustments in the RMB to defuse the risk of an international confrontation. 


\section{Stabilization policy}

A recent study by Ma, Y. (2016) provides a new approach to investigate monetary policy nonlinear within a micro-founded DSGE model by incorporating a transition function into the traditional Taylor rule. The model is estimated using the Bayesian method for the Chinese economy over the period 1998-2013. The empirical results show that the central bank of China actually adopts a nonlinear Taylor rule and pursues an inflation target zone of $[1 \%, 5 \%]$ rather than sticking to a rigid target. Further results from impulse responses and welfare comparisons suggest that economic stabilization is an important motive in the conduct of monetary policy in China and the adoption of a nonlinear rule seems to serve this goal better than the traditional linear rule.Chang, C et al.(2016) also argued that China's central bank, the People's Bank of China (PBOC), frequently uses reserve requirements (RR) as a policy instrument for macroeconomic stabilization. Since 2006, the PBOC has adjusted the required reserve ratio at least 40 times. Changes have also been substantial.

Since the Asian financial crisis of 1997-1998, China has significantly increased its foreign exchange reserves. The authors argued that the resulting abnormal levels of currency reserves accumulated by Chinese authorities are not intended to maximize the citizenry's economic welfare, as a precautionary account, but rather to forestall the elite's own political demise. This goal has been pursued mainly by generating large current account surpluses through manipulation of the yuan exchange rate Seghezza, E et al.(2017).

\subsection{The Innovation in China}

Liu, X et al. (2017) argued that since it embarked on its economic opening and reform path in the late 1970s, the Chinese government has assigned a central role to science, technology and innovation for the country's economic development. In the phase of 'economic catch-up', China has pursued a top-down innovation policy, characterized by targeted investments in science and technology. Recently, a significant shift in China's innovation policy can be discerned, with government increasingly acknowledging the importance of 
markets, private enterprises and favorable institutional conditions as determinants of a well-functioning innovation system.

Prodi, G et al.(2017) found that the emergence of 'subnational innovation spaces' in China as they result from the interaction between state restructuring and the diffusion of innovative activities. Several countervailing forces have played a part in outlining a number of supra-urban regions that diverge by their own capability to develop and govern innovation-related socioeconomic processes. On the one hand, the downscaling of state power enables the local administrative units to plan place-based strategies to embed technological upgrading, such as driving indigenous innovative activities to cluster around industrial and technological parks.

Further authors for instance, Chen, J et al.(2017) found that Eco-innovation has become a core engine for long-term stable economic development, as well as a fundamental way to ease the tension between economic growth and environmental resources management. Through the construction of a measurement index system, this paper evaluates the level of regional Eco-innovation in 30 Chinese provinces from 2000 to 2014.

However, the regional comparison of the Eco-innovation index revealed an obvious, gradually decreasing distribution pattern from east to west. Factors such as technology push, market pull, and environmental regulation pull have positive but differentiated influences on the Eco-innovation throughout China and among the eastern, central and western regions.

\subsubsection{Patterns of Innovation Growth}

According to Zhang, W. (2017) the last 30 years of high growth rates were primarily China's latecomer advantage unleashed by reform and opening. This latecomer advantage provided entrepreneurs with tremendous opportunities for arbitrage. It is the arbitrage activities of entrepreneurs (both Chinese and foreign) that caused a gradual increase in the efficiency of resource allocation, and thus drove high rates of economic growth. However, as the gap between China and developed countries has decreased, the room for arbitrage is 
shrinking. Solely relying on arbitrage entrepreneurs will no longer sustain high rates of economic growth.

A recent study by Chen, $\mathrm{Z}$ et al.(2017) also investigated the relationship between imports and innovation by importing firms. We first construct a theoretical model in which imports stimulate innovation through cost-reducing knowledge spillovers. We then employ a combined micro dataset of Chinese manufacturing firms to estimate the effects of imported intermediates on the firm's R\&D investment.

More scholars for instance Cheng, Y et al.(2017) also argued that the increasingly large role of financial intermediaries in promoting firms' innovation and internationalization has led to great research interest. China has faced mounting pressure to take entrepreneurial finance and innovation seriously. Little is known about entrepreneurial financiers' activities and performance. Focusing on entrepreneurial financiers' activities in the Yangtze River Economic Belt, authors investigated how they select projects and how well they perform in China. Evidence shows that various financiers serve in the financial system to nurture innovative entrepreneurial activities; they tend to focus on technology, and the major financiers vary with stage of industrial technological development.

Further study by Zhao, C et al. (2017) figure out that in China's new normal, a strategy named "Made in China 2025" was proposed to speed up the manufacturing's transformation and upgrading. The hardship of China's manufacturing industry transformation and upgrading are the limit capability of independent innovation, the complexity and variability for competitive environment and the existence of institutional hurdles.

At present, China is facing the powers of the industry from manufacturing to major, authors used factor analysis method to construct the evaluation index system of innovation-driven ability of Chinese manufacturing industry, and established evaluation model of innovation-driven ability of Chinese manufacturing industry.

Lee, $\mathrm{K}$ et al. (2017) applied the industrial catch-up in four sectors in China. 
The technological regime of sectors affects the chance for latecomers to catch up, but the final outcomes also depend on the actions of governments and firms. A successful catch-up requires the growth of indigenous firms rather than dependence on foreign direct investment. The government has an important role, but different forms of intervention across sectors must be identified.

A lot of scholars for example, Wonglimpiyarat, J et al.(2017) are concerned with China's strategies in remodelling itself towards an innovation-driven economy. In particular, the study is focused on exploring the policies and innovation strategies to support high-tech SMEs in China. The authors have shown that the Chinese government has introduced many policy initiatives (government intervention policies) after the country joined the

World Trade Organization (WTO). However, the country still needs policies to improve interactions among institutions within the innovation system.

According to Shcherbiak, A. (2017), China's recent economic growth has turned the country into one of the major players in the global economy. However, the benefits of that growth have not been evenly distributed among the population. As the growth rate is losing its double-digit power, the economy is transitioning into innovation-driven growth that prioritizes science and technology development over mass production.

$\mathrm{Qu}, \mathrm{Y}$ et al.(2017) investigated the role of regional formal institutions in the innovation process in Chinese enterprises. The authors suggested that regional formal institutions (reflected by government support), financial institutions, educational institutions and taxation institutions promote innovation in Chinese firms, while they fail to discover such an impact from legal institutions. Also, regional formal institutions positively moderate Foreign Direct Investment (FDI) spillovers on process innovation.

\section{Misallocation of Innovation Resources}


Many researchers for example, $\mathrm{Li}, \mathrm{H}$. C et al.(2017) sound an alarm about disparate efficiency among China's regions in the allocation of innovation inputs.

A theoretical measure of misallocation is adopted to gauge the distortions that exacerbate the inefficiency of resource allocations across geographic innovation units; these units' usage of innovative inputs reveals the level of misallocations prevalent within the Chinese economy. The measure of innovation misallocation is computed by utilizing a micro dataset based on information from the China Statistical Yearbook for Science and Technology (CSYST) from 1999 to 2012. In addition, the authors probed the factors that co-move with China's innovation resource misallocations. The scholars found that, although an advanced financial market is beneficial to innovation efficiency in China, both the government's extensive development of transportation infrastructure and the preferential treatment given to state-owned enterprises (SOEs) and foreign-invested enterprises (FIEs) negatively correlate with innovation efficiency.

Wei, C et al.(2017) point out that, despite the important policy and welfare implications of China's energy issues, to date there has been little investigation from a micro-level perspective of the misallocation of resources in manufacturing enterprises. To fill this gap,

the authors deal with resource misallocations in China with special reference to energy and labor inputs. Using a large, novel dataset of manufacturing enterprises from Zhejiang province, they employ a simultaneous system of equations for (gross) industrial output value, wage bill, energy expenditure and carbon emissions. The explanatory variables include labor, educational attainment of employees, capital value, materials, and a list of energy-related variables. Their results show that, for the same energy content, non-coal energy inputs are more productive than coal and coal-related fuels. Non-coal energy is more environmentally friendly but more expensive than coal-related fuels. Using the model estimates, authors conduct Wald tests on whether the marginal productivity of labor and energy significantly differ from their respective factor costs.

\section{Conclusion}

After more than three decades of high rise that was focused on an exploration of its low-wage profit and almost positive demographic pattern in correlation with 
market-oriented reforms and openness to the global economy, China is at a change with a significant higher practice and a shrinking work force. Prospective growth by necessity would have to depend more on its capacity to achieve productivity rise, and national innovation will be an important part of it. In this paper, we assess the likelihood that China can make the necessary transition. Applying data on investment, and patent applications, receipts, and citations, we figure out that the Chinese economy has become increasingly innovative, including reforms. In terms of drivers of innovation growth, we find that embracing expanded retail opportunities in the world economy and responding to boosting labor costs are two leading contributing causes. Further, we find clue of resource misallocation in the innovation area: Although state-owned companies earn further subsidies, private companies exhibit extra innovation outcome. Innovation can presumably progress even faster if resource misallocation can be undertake.

We have point out that Chinese companies have demonstrated a capacity to become more innovative in response to conduct pressure and global opportunities. The data on Chinese patents, both from a quantity and a quality future, occur encouraging enough that there is no reason to be overly pessimistic about China's prospects for a prosperity transition to a more innovationbased growth approach. If China finds efficient measures to bring a transformation to a more innovative economy, it can materialize its dream faster of moving into the high-income. The Chinese government subsidies contribute to favor

state-owned companies, and yet both national private sector firms and foreign invested firms are more effective in transforming expenditure in $R \& D$ to innovation issues as measured by patents. Leveling the playing field for firms of all ownership type, limiting the government's discretion in subsidies for research and development, and secure that private sector firms have a fair chance at receiving those subsidies would cut down resource misallocation and enhance adaptability. 


\section{Reference}

Ansar, A., Flyvbjerg, B., Budzier, A., \& Lunn, D. (2016). Does infrastructure investment lead to economic growth or economic fragility? Evidence from China. Oxford Review of Economic Policy, 32(3), 360-390.

Alder, S., Shao, L., \& Zilibotti, F. (2016). Economic reforms and industrial policy in a panel of Chinese cities. Journal of Economic Growth, 21(4), 305-349.

Brooks, S. G., \& Wohlforth, W. C. (2016). The Once and Future Superpower.Foreign Affairs, 95(3), 11.

Basu, D., \& Miroshnik, V. (2015). Economic Reforms in China. InInternational Business and Political Economy (pp. 174-191). Palgrave Macmillan UK.

Curtis, C. C. (2016). Economic reforms and the evolution of China's total factor productivity. Review of Economic Dynamics, 21, 225-245.

Chen, Z., Zhang, J., \& Zheng, W. (2017). Import and innovation: Evidence from Chinese firms. European Economic Review, 94, 205-220.

Cheng, Y., Liu, W., \& Lu, J. (2017). Financing Innovation in the Yangtze River Economic Belt: Rationale and Impact on Firm Growth and Foreign Trade.Canadian Public Policy, 43(S2), S122-S135.

Chang, C., Liu, Z., Spiegel, M. M., \& Zhang, J. (2016). Reserve requirements and optimal Chinese stabilization policy (No. 2016-10).

Chen, J., Cheng, J., \& Dai, S. (2017). Regional eco-innovation in China: An analysis of eco-innovation levels and influencing factors. Journal of Cleaner Production, 153, 1-14.

Gao, Z. (2017). A Reflection on China's Economic Reform from the Perspective of Catholic Social Teaching (Forthcoming). International Journal of Public Theology.

Gunby, P., Jin, Y., \& Reed, W. R. (2017). Did FDI Really Cause Chinese Economic Growth? A Meta-Analysis. World Development, 90, 242-255.

Glawe, L., \& Wagner, H. (2017). A Stylized Model of China's Growth Since 1978. 
Lee, K., Gao, X., \& Li, X. (2017). Industrial catch-up in China: a sectoral systems of innovation perspective. Cambridge Journal of Regions, Economy and Society, 10(1), 59-76.

Lin, J. Y., Wan, G., \& Morgan, P. J. (2016). Prospects for a re-acceleration of economic growth in the PRC. Journal of Comparative Economics, 44(4), 842-853.

Liu, X., Schwaag Serger, S., Tagscherer, U., \& Chang, A. Y. (2017). Beyond catch-upcan a new innovation policy help China overcome the middle income trap?. Science and Public Policy.

Li, H. C., Lee, W. C., \& Ko, B. T. (2017). What determines misallocation in innovation? A study of regional innovation in China. Journal of Macroeconomics, 52, 221-237.

Liu, W. H., \& Langhammer, R. J. (2016). China's growth challenges (No. 101). Kiel Policy Brief.

Ma, G., Roberts, I., \& Kelly, G. (2017). Rebalancing China's Economy: Domestic and International Implications. China \& World Economy, 25(1), 1-31.

Ma, Y. (2016). Nonlinear monetary policy and macroeconomic stabilization in emerging market economies: Evidence from China. Economic Systems,40(3), 461-480.

Nagaraj, R. (2017). Economic Reforms and Manufacturing Sector Growth.Economic \& Political Weekly, 52(2), 61.

Ning, Y., Wang, Y., Yang, Z., \& Geng, Y. (2017). Measurement and multifractal properties of short-term international capital flows in China.Physica A: Statistical Mechanics and its Applications, 468, 714-721.

Qu, Y., Qu, T., \& Wu, Y. (2017). The role of regional formal institutions and foreign direct investment in innovation in Chinese enterprises. Asia Pacific Business Review, 23(1), 27-43. 
Overholt, W. H. (2016). China and the evolution of the world economy. China Economic Review, 40, 267-271.

Prodi, G., Nicolli, F., \& Frattini, F. (2017). State restructuring and subnational innovation spaces across Chinese prefectures. Environment and Planning C: Government and Policy, $0263774 X 16664519$.

Shcherbiak, A. (2017). The Effect of Innovation on China's Distribution of Income.

Seghezza, E., Morelli, P., \& Pittaluga, G. B. (2017). Reserve accumulation and exchange rate policy in China: The authoritarian elite's aim of political survival. European Journal of Political Economy, 46, 40-51.

Suzuki, T. (2017). The Renminbi Exchange Rate Reform and Its Implications for Asian Markets. China Quarterly of International Strategic Studies, 1650031.

Shen, W. (2016). A New Era for China's Renewable Energy Development? External Shocks, Internal Struggles and Policy Changes (No. IDS Evidence Report; 196). IDS.

Tong, J. T., \& McManus, J. (2017). China's economic growth and future prosperity. Strategic Change, 26(3), 281-285.

Tong, J. T., \& McManus, J. (2017). China's economic growth and future prosperity. Strategic Change, 26(3), 281-285.

Wilson, R. (2016). Does governance cause growth? Evidence from China.World Development, 79, 138-151.

Wei, C., \& Li, C. Z. (2017). Resource misallocation in Chinese manufacturing enterprises: evidence from firm-level data. Journal of Cleaner Production, 142, 837-845.

Wonglimpiyarat, J., \& Khaemasunun, P. (2017). Strategies of remodelling China towards an innovation-driven economy. International Journal of Business Innovation and Research, 12(2), 175-188. 
Weiss, J. C., \& Wichowsky, A. (2016). External Influence on Exchange Rates: An Empirical Investigation of US Pressure and the Chinese RMB.

Xianhong, X., Tian, C., \& Jinnuo, Z. (2016, December). Influence Effect of International Capital Flow on China's Economic Growth. In Applied Computing and Information Technology/3rd Intl Conf on Computational Science/Intelligence and Applied Informatics/1st Intl Conf on Big Data, Cloud Computing, Data Science \& Engineering (ACIT-CSII-BCD), 2016 4th Intl Conf on (pp. 329-331). IEEE.

$\mathrm{Yu}$, H. (2017). Motivation behind China's 'One Belt, One Road'Initiatives and Establishment of the Asian Infrastructure Investment Bank. Journal of Contemporary China, 26(105), 353-368.

Zhengge, T. U., \& Renjun, S. (2016). Productivity growth in China's large industrial firms: patterns, causes, and implications. Journal of Chinese Studies, 1(1), 2.

Zhao, C., Liao, S., \& Li, J. (2017). The Evaluation Index System of Innovation-Driven Capability of Chinese Manufacturing Industry Based on Factor Analysis. In MATEC Web of Conferences (Vol. 100, p. 03023). EDP Sciences.

Zhang, W. (2017). China's future growth depends on innovation entrepreneurs.Journal of Chinese Economic and Business Studies, 15(1), 19-40. 